\title{
Parenting Skills and Social-Communicative Competence in Childhood
}

Craig H. Hart

Brigham Young University - Provo, craig_hart@byu.edu

Lloyd D. Newell

Brigham Young University - Provo

Susanne Frost Olsen

Brigham Young University - Provo

Follow this and additional works at: https://scholarsarchive.byu.edu/facpub

Part of the Other Social and Behavioral Sciences Commons

\section{Original Publication Citation}

Hart, C. H., Newell, L. D., Olsen, S. F. (2003). Parenting skills and social/communicative competence in childhood. In J. O. Greene \& B. R. Burleson (Eds.), Handbook of Communication and Social Interaction Skill (pp. 753-797). Mahwah, NJ: Lawrence Erlbaum Associates.

\section{BYU ScholarsArchive Citation}

Hart, Craig H.; Newell, Lloyd D.; and Olsen, Susanne Frost, "Parenting Skills and Social-Communicative Competence in Childhood" (2003). Faculty Publications. 4133.

https://scholarsarchive.byu.edu/facpub/4133

This Book Chapter is brought to you for free and open access by BYU ScholarsArchive. It has been accepted for inclusion in Faculty Publications by an authorized administrator of BYU ScholarsArchive. For more information, please contact ellen_amatangelo@byu.edu. 


\title{
PARENTING SKILLS AND SOCIAL-COMMUNICATIVE COMPETENCE IN CHILDHOOD
}

\author{
Craig H. Hart \\ Lloyd D. Newell \\ Susanne Frost Olsen \\ School of Family Life, Brigham Young University, Provo, Utah
}

The ways that children implement social and communication skills in peer-group interaction provide the foundation for successful later life adjustment (Rubin, Bukowski, \& Parker, 1998). Research findings suggest that a host of variables are involved (Hart, Olsen, Robinson, \& Mandleco, 1997). These include family processes involving marital and sibling relationships, parenting (e.g., Dunn, 2002; Hart, Nelson, et al., 2000; Stafford \& Bayer, 1993), biologically based genetic and temperament factors (e.g., Pike, 2002; Plomin \& Rutter, 1998; Sanson, Hemphill, \& Smart, 2002), and extrafamilial influences, including the peer group, schools, media, and culture (e.g., Hart, Yang, Nelson, Jin, \& Nelson, 1998; Howes \& James, 2002; Ladd, Buhs, \& Troop, 2002; McDougall, Hymel, Vaillancourt, \& Mercer, 2001).

The focus of this chapter is on parenting linkages to social and communicative skill outcomes in children during early and middle childhood. Our aims are threefold. First, we conceptualize the nature of social and communicative skills that lend themselves to peer-group success across early and middle childhood. The practical significance of these skills for psychosocial adjustment and the consequences of low skill development are discussed. Second, parenting skills that can enhance or diminish the formation of child competencies are considered, as are the complex interplay between nature and nurture that results in individual differences among children. We take issue with recent arguments suggesting that parents matter little in children's development (Harris, 1998, 2000, 2002). Third, we overview intervention studies that are designed to enhance parenting skills and child competencies and that may result in subsequent changes in child social and communicative outcomes.

Preparation of this chapter was supported by the Family Studies Center at Brigham Young University. 


\section{CHILD SOCIAL-COMMUNICATION SKILLS}

Skilled social behavior is more likely to result in positive psychosocial outcomes (e.g., less loneliness, more acceptance by peers) and more meaningful relationships between individuals (see Asher, Parker, \& Walker, 1996; Rubin, Coplan, Nelson, \& Lagace-Seguin, 1999; Sampter, this volume). Behavioral and communicative manifestations of sociable behavior include conforming and friendly, amicable behavior; emotional impulse control; leadership; assertiveness; prosocial orientations (i.e., helping, sharing, comforting); and person-centered communication (Burleson \& Kunkel, 1996; Hart et al., 1997). Children's social competence has not always been defined in ways that explicitly specify the importance of communication abilities (Rose-Krasnor, 1997), however, consider often-cited definitions such as the following:

- the ability to accomplish interpersonal tasks ... the ability to manipulate other's responses (Weinstein, 1969, p. 755)

- the attainment of relevant social goals in specified social contexts, using appropriate means and resulting in positive developmental outcomes (Ford, 1982, p. 323)

- the formulation and adoption of personal goals that are appropriate and adaptive to specific social situations and implementing effective behavioral strategies for achieving goals (Taylor \& Asher, 1984, p. 57)

Definitions of social competence like these imply communicative competence (Dodge, 1985; Gresham, 1986; Odom \& McConnell, 1992). The essence of social competence in relationships is communication skill, whether it be verbal or nonverbal in nature (e.g., Burgoon, 1994; Duck, 1989; Iverson \& Goldin-Meadow, 1998).

\section{Social and Communicative Competence}

Germane to many definitions of social competence is the implication that personal and relational goals can be achieved through interpersonal problem-solving strategies that involve communication skills. For example, Rubin and colleagues defined social competence as "the ability to achieve personal goals in social interaction while simultaneously maintaining positive relationships with others over time and across situations" (Rubin \& Rose-Krasnor, 1992, p. 285). This "encompasses skills and abilities relating to all aspects of interpersonal problem solving, from the self-regulation of emotions aroused in social interaction, to the negotiation of solutions in interpersonal conflicts" (Mills \& Rubin, 1993, p. 98). Negotiation requires functional communication competence, which is "the ability to use communicative resources strategically to accomplish personal and social goals-to persuade, inform, console, appease, compromise, or the like" (Burleson, Delia, \& Applegate, 1995 p. 36).

Taken together, these definitions provide a foundation for behavioral and communicative indicators of social competence that are well supported by research. For example, socially skilled children are better able to discern the emotional states of others and are more capable of regulating their own emotions (e.g., Denham, von Salisch, Olthof, Kochanoff, \& Caverly, 2002). They also tend to expect that sociable behavior will lead to instrumental gains and enhanced relations with peers in interpersonal conflict situations (Hart, DeWolf, \& Burts, 1992; Hart, Ladd, \& Burleson, 1990), and they communicate in socially contingent and relevant ways during social 
interaction (e.g., Black \& Logan, 1995; Guralnick, Conner, Hammond, Gottman, \& Kinnish, 1996; Kemple, Speranza, \& Hazen, 1992; Steinkamp, 1989).

The importance of communication skills in social interaction is well exemplified in recent research on school-age children with specific language impairments (SLI). Some children with SLI have been found to have difficulty entering ongoing conversations, collaborating, negotiating, and making joint decisions (Brinton \& Fujiki, 2002). They are also prone to being anxious and wary in peer-group situations (Fujiki, Brinton, Morgan, \& Hart, 1999). Although children with SLI are often accepted by peers, deficits in language abilities appear particularly detrimental to friendship formation and maintenance functions that are inherent in close relationships (Fujiki, Brinton, Hart, \& Fitzgerald, 1999).

Unlike general acceptance by a group of peers, friendship requires reciprocity and feelings of perceived equality between children that are manifested in close, mutual, and voluntary dyadic bilateral relationships (cf. Hartup \& Abecassis, 2002; Rubin, Coplan, et al., 1999). Friendships are built "upon a foundation of interpersonal skills" (Asher et al., 1996, p. 387), many of which are expressed through language. Accordingly, Fujiki, Brinton, Hart et al. (1999) speculated that many children with SLI may lack abilities in coordinating linguistic-formulation demands associated with expressing concern and affection, self-disclosing ideas and feelings, and resolving conflict. Deficiencies in this regard imply less "ability to use communicative resources strategically to accomplish personal and social goals" (Burleson, Delia, \& Applegate 1995) "while simultaneously maintaining positive relationships with others over time and across situations" (Rubin \& Rose-Krasnor, 1992, p. 285).

\section{Social and Communicative Skill Deficiencies}

Social competence has also been framed as a "judgment call" based on how an audience views an actor's behavioral repertoire (McFall, 1982). Deficiencies in social and communicative competence can be thought of in terms of externalizing and internalizing behaviors that are not positively perceived by others (Rubin, Stewart, \& Chen, 1995). These, along with sociability, will serve as key constructs around which the remainder of our review is organized. Individual behavioral and communicative deficits reflected in internalizing and externalizing behavior have implications for how well children form close relationships with others, as well as for their abilities to appeal to group norms that serve as criteria for peer acceptance or rejection (Rubin et al., 1998).

Externalizing Behavior. Externalizing is a global category of child maladjustment that captures aggressive, angry, impulsive and disruptive, oppositional, and nonconforming behaviors (e.g., Campbell, 1995; Eisenberg et al., 1999; Hinshaw, 1997). Children who display externalizing behavior are more likely to communicate their desires verbally in a less skillful, noncontingent manner (e.g., Black \& Logan, 1995; Kemple et al., 1992) and are prone to envision antisocial behaviors as a means for achieving desirable goals to the exclusion of relationship considerations during interpersonal conflicts (e.g., Chung \& Asher, 1996; Crick \& Werner, 1998; Dodge \& Price, 1994; Hart et al., 1990; Murphy \& Eisenberg, 1996).

Much of the research on externalizing disorders has focused on aggressive and disruptive behavior in the context of other antisocial behavior patterns that include noncompliance with adults, delinquency, substance abuse, and vandalism (Coie \& Dodge, 1998). Because such behavior is typically viewed negatively by noncolluding 
agemates, aggressive or disruptive enactment directed toward others in friendship or peer-group contexts generally leads to attenuated relationships and rejection by peers (e.g., Aboud \& Mendelson, 1996; Hart, DeWolf, Wozniak, \& Burts, 1992; Hart, McGee, \& Hernandez, 1993). There are exceptions to the pattern, however. When this type of negative behavior is conjoined with high levels of athleticism or physical attractiveness or with lower levels of shyness and higher academic competence, antisocial boys are often popular with peers (Rodkin, Farmer, Pearl, \& Van Acker, 2000).

Recent research on externalizing behavior has focused on subtypes of aggression with the realization that different forms of aggression often co-occur in early and middle childhood (e.g., Crick, Casas, \& Ku, 1999; Galen \& Underwood, 1997; Hart, Nelson, et al., 2000). For example, physicalaggression is conceptualized as hostile acts that harm others for intimidation purposes or instrumental gains by pushing, hitting, intimidating, or verbally threatening with physical harm (e.g., Crick, Werner, et al., 1999). Social aggression consists of verbal disparagements (e.g., teasing, mocking, making fun of, making sarcastic comments, name calling) and nonverbal hostilities such as disdainful facial expressions or body movements such as rolling one's eyes or tossing one's hair to convey contempt (Galen \& Underwood, 1997). Relational aggression is another form of hostility that includes a class of exclusionary behaviors that harm others through intentional damage (or threat of damage) to relationships or social standing (e.g., Crick, Werner, et al., 1999; Hart, Nelson, et al., 1998). Children who display this pattern of aggression typically rely on verbal attacks (e.g., threatening not to invite another child to a birthday party unless the child does what is wanted, gossiping, rumor spreading) and nonverbal forms of aggression (e.g., walking away when angry or enacting the "silent treatment").

Internalizing Problems. Internalizing problems are often characterized by negative internal states that include sadness, depression, loneliness, embarrassment, anxiety, and fearfulness (e.g., Gresham \& Elliott, 1990; Ialongo et al., 1996). There is some evidence to suggest that social anxiety, for example, is associated with children being less adept at enacting competent reciprocal negotiations in interpersonal conflicts with peers (Adalbjarnardottir, 1995), even though they may possess the underlying social-cognitive knowledge for how to do so (e.g., Rubin et al., 1998).

When extreme, these internal states play out in certain types of withdrawn peergroup behavior that are negatively viewed by others. For example, recent research suggests that childhood reticence, operationalized as the frequent production of onlooking and unoccupied behavior, reflects social fear and anxiety in both familiar and unfamiliar social contexts (e.g., Coplan, Rubin, Fox, Calkins, \& Stewart, 1994; Rubin, Burgess, \& Coplan, 2002). This form of "being alone" appears to stem from conflict between social approach and avoidance motivations (Asendorpf, 1990). Such behavior has been associated with peer rejection during early childhood in numerous cultural contexts (Hart, DeWolf, \& Burts, 1993; Hart, Yang, et al., 2000; Rubin \& Clarke, 1983); however, other forms of withdrawal denoted as solitary passive "playing alone" (e.g., quiet exploration of objects or construct activity) are viewed by younger children as normative (Ladd \& Burgess, 1999). As children grow older, however, solitary passive behavior blends with reticence to become a unitary construct of withdrawal that becomes highly salient to peers (Asendorpf, 1993). Children displaying withdrawal in mid-to-late childhood feel more lonely, seldom initiate exchanges with peers, and are more likely to be rejected (Rubin et al., 2002). Possibly, children with internalizing problems display patterns of social reticence or unassertive social 
and communicative strategies, and this profile of behavioral solitude may lead others to perceive them as being less socially skilled (e.g., Giles \& Street, 1994; Rubin et al., 1995).

\section{NATURE, NURTURE, AND SOCIAL-COMMUNICATIVE COMPETENCE}

How do childhood social skills reflected in sociable behavior develop? In what ways do social skill deficiencies characterized by externalizing and internalizing risk factors emerge? The answers to these questions typically involve interactions between biological predispositions and environmental factors that include parental socialization practices (Coie \& Dodge, 1998; Rubin, Coplan, et al., 1999; Pike, 2002). Research conducted by molecular and behavioral geneticists, temperament researchers, and physiologists provide some clues into how complex transactional processes between nature and nurture may play out in the development of social skills and risk factors (Hill \& Maughan, 2002). Before exploring ways that parenting skills might contribute to children's behavior, we discuss the complexity of nature-nurture interactions. With this in mind, parenting skills can be considered with regard to the relative influence they might have in the context of other factors.

Genetic predispositions for risk or ability factors are by no means deterministic (Plomin \& Rutter, 1998). There are likely multiple genes associated with risk (e.g., internalizing, externalizing) or ability (e.g., sociability), accompanied by multiple environmental risk or ability enhancers. These are quantitatively distributed in ways that contribute to the probability of a risk factor or an ability factor manifesting itself in actual child behavior. In other words, certain combinations of genes likely contribute to probabilistic risks or abilities when accompanied by the right combination of probabilistic environmental risk or ability enhancers. Although single genetic or environmental risk or ability factors may be necessary for individual development, it should be emphasized that none is sufficient by itself to facilitate sociability or internalizing and externalizing behavioral tendencies (Wachs, 2000).

Because individuals can be distributed across a continuum of multiple genetic and environmental probabilities for risk or abilities, social-communicative skills can vary considerably among individuals. Hypothetically, for example, children with higher genetic predispositions toward aggressive or impulsive externalizing behavior would likely be at more risk for displaying this behavior in peer-group settings if they are reared in environments that provide access to the viewing of violent media and the modeling of hostile parent-child and peer-group interactions (cf. Wachs, 1999). As an illustration, there is some evidence that a child's tendency to watch television may be partially determined by genetic factors (Plomin, Corley, DeFries, \& Fulker, 1990) and that high trait-aggressive individuals are more likely to watch violent media than low trait-aggressive individuals (Bushman, 1995). Alternatively, children with lower genetic risk may be less likely to act violently when exposed to parental or media violence because they are less susceptible to hostile environmental influence (cf. Belsky, Hsieh, \& Crnic, 1998).

\section{Molecular Genetics Research}

Few genetic markers have been discovered that contribute to probabilistic risk (not deterministic risk) and differential susceptibility to environmental influence. For example, DRD4 has been linked to novelty-seeking behavior that may be played out in some forms of externalizing disorder, but it only accounts for about $4 \%$ of the variance 
in behavior, suggesting that many other factors come into play as well (Plomin \& Rutter, 1998). No firm genetic markers have been found specifically for aggression (Siminoff, 2002) or for most other behavioral characteristics. This may change with recent advances in gene mapping (Plomin, 2000).

Even as more genetic markers are discovered, critics argue that this knowledge may still not tell us exactly how or why some individuals may choose to override certain biological tendencies and others do not (e.g., Shaffer, 2000). Moreover, gene systems that underlie the expression of specific behavioral dimensions may turn on or turn off at different points of development (Plomin, DeFries, McClearn, \& Rutter, 1997), making it even more challenging to assess the stability of biological predispositions across time. Additional evidence indicates that environmental influences can determine which regulator genes operate to modify biological aspects of human development (e.g., temperament-related neural-hormonal systems, central nervous system). All this makes it difficult to ascertain whether it is self-will, developmental change (nature), or environmental influence (nurture) that has primacy in modifying biological underpinnings for behavioral expression (Wachs, 1999).

\section{Behavioral-Genetics Research}

Although the identification of behavioral-genetic markers in molecular genetics research is in its infancy, hereditary influences have been estimated indirectly in behavior genetic research for several decades (Pike, 2002). This approach relies primarily on twin and adoption studies (Plomin et al., 1997). Researchers try to gauge genetic influence from comparisons between genetically related relatives versus adoptive relatives (e.g., nonadoptive siblings versus adoptive siblings) and between genetically related individuals reared apart (e.g., twins adopted separately). Studies using variations of these designs suggest that there may be significant genetic influence for externalizing problems (e.g., Deater-Deckard, 2000; Eley, Lichtenstein, \& Stevenson, 1999; Leve, Winebarger, Fagot, Reid, \& Goldsmith, 1998), sociability (e.g., Plomin, 1994; Tellegen et al., 1988), and inhibited or withdrawn behavior (Robinson, Kagan, Reznick, \& Corley, 1992).

\section{Physiological Perspectives}

A host of physiological factors have also been considered in the development of sociable, internalizing, and externalizing behavior (see Coie \& Dodge, 1998; Fox, Henderson, Rubin, Calkins, \& Schmidt, 2001; Rubin et al., 2002). For example, when measuring electrical brain activity, resting right frontal EEG activity is associated with children's social fear, anxiety, and withdrawal, whereas left frontal EEG activity has been linked to sociability. Likewise, vagal tone, which marks the ability to regulate one's level of arousal, has been shown to distinguish inhibited from noninhibited infants and toddlers. Elevated baseline cortisal readings also differentiate more socially wary and fearful children from less inhibited children. Finally, externalizing behavior has also been linked to a number of hormonal, neurochemical, autonomic, and neurophysiological factors.

\section{Temperament Research}

Temperament studies focus on individual differences in behavioral style that can be observed beginning in early childhood. There is some scientific support for the 
generally accepted view that temperament is biologically based (e.g., Rothbart \& Bates, 1998). Although multitudes of temperament categories have been studied, Sanson et al. (2002) noted an emerging consensus that three broad classifications best represent these behavioral styles. These include reactivity-negative emotionality (e.g., irritability, anger, inflexibility, or distress to novelty and fear reactions), selfregulation (e.g., emotional control, nondistractibility, persistence), and approachinhibition (e.g., inclination to approach novel situations and people or to be wary and withdrawn).

Broadly speaking, concurrent and longitudinal findings indicate that higher levels of inhibition and fearfulness are associated with more withdrawal from peers (e.g., Rubin et al., 2002). Conversely, less inhibition has been linked to more sociability with peers (e.g., Skarpness \& Carson, 1986; Stocker \& Dunn, 1990). High negative emotionality (as in irritability, inflexibility) and low self-regulation is associated with more externalizing behavior (see Sanson et al., 2002), whereas low negative emotionality and higher levels of self-regulation and approach are linked to more sociability with peers (e.g., Eisenberg et al., 1993). More recent findings suggest that negative emotionality, in the presence of optimum regulation, leads to better social functioning, whereas high emotionality accompanied by low regulation is a risk for externalizing behavior problems and later social competence (Belsky, Friedman, \& Hsieh, 2001; Eisenberg, Fabes, Guthrie, \& Reiser, 2000). Similarly, temperamentally outgoing children who lack emotional regulation have been found to be more aggressive and disruptive with peers (Rubin, Coplan, Fox, \& Calkins, 1995).

\section{The Nature Part of Nurture}

In light of biological predispositions that appear to affect behavior (in a probabilistic not deterministic sense), recent studies suggest that their impact is likely manifested in an indirect manner by influencing the experiences children evoke from others or create for themselves (e.g., Deater-Deckard, 2000). Plomin, Reiss, Hetherington, and Howe, (1994) suggested that "children are not passive receptacles for environmental influences - they select, modify, and even create their environments" (p. 32), resulting in actual and perceived differences in how others respond toward them. Thus, genetic predispositions can elicit different responses from environmental sources (e.g., parents, siblings, peers) in ways that result in different child outcomes (Pike, 2002; Vandell, 2000).

Child Influences. As noted by Scarr and McCartney (1983), because parents provide their children with genes, the rearing environments to which children are exposed correlate to some degree with their own genotypes. For example, a child with sociable tendencies may passively fit in with, and even amplify, more sociable behavioral patterns in family interaction exhibited by one or both parents with whom he or she shares most common genetic characteristics. For siblings, varying social abilities displayed by children in the same family may stem from greater genetic similarity with one parent over another. Accordingly, siblings in the same family may evoke unique responses from one or both parents. Research suggests that although there are shared parenting influences in two-parent families (Russell \& Russell, 1994), different siblings in the same family, by their very natures, can evoke different parenting behaviors from mothers and fathers (e.g., Holden \& Miller, 1999; Kandel \& Wu, 1995; Sanson \& Rothbart, 1995; Volling \& Elins, 1998), particularly as children grow older (O'Connor, Deater-Deckard, Fulker, Rutter, \& Plomin, 1998). Even children 
understand that parents adjust their styles to different needs and personality characteristics of their siblings (Kowal \& Kramer, 1997).

Children may also actively seek out experiences that provide a good "fit" with their temperamental predispositions (Thomas \& Chess, 1977). This, in turn, tends to result in differential parental response. Relative to a more sociable sibling, for example, a more inhibited child may prefer to spend more time in solitary activities (such as coin or stamp collecting) or in anxious, hovering behaviors during peer-group interaction. Research indicates that parents typically respond to a more sociable child by facilitating more interactions with peers (e.g., Profilet \& Ladd, 1994). Alternatively, parents of inhibited children tend to engage in highly directive (e.g., telling a child how to act, readily intervening to solve interpersonal dilemmas) or overprotective behavior (e.g., shielding a child from social failure). Such parenting has been shown to maintain or exacerbate, rather than resolve their child's difficulties (Rubin et al., 2002; Rubin, Burgess, \& Hastings, 2002). For externalizing behavior, research suggests that children with more spirited dispositions (e.g., aggressive, highly emotional, or thrill-seeking tendencies) may raise concerns and evoke more formal intervention by parents in terms of rules, redirection, and monitoring than children who are more sociable and conforming (e.g., Hart, Yang, et al., 1998; Ladd \& Golter, 1988; Mize, Pettit, \& Brown, 1995). This appears to be the case in particular when child behavior falls outside cultural norms and family expectations (Bell \& Chapman, 1986; Wachs, 1999).

Shared and Nonshared Effects. Environmental sources such as differential parental treatment that touch siblings in unique ways are referred to as nonshared effects. Nonshared effects can also result from children responding to similar environmental influences in different ways (Deater-Deckard, 2000). Children may respond to similar parenting styles according to how experiences are filtered through their individual perceptions (Dunn, 2002; Grusec, 2002). For example, a more externalizingprone child may perceive parental coercion as confrontational and might often react by mouthing off and acting out in more openly defiant and angry ways. Alternatively, a temperamentally anxious-fearful sibling may view parental coercion (e.g., yelling and commanding) as threatening. He or she may respond by dutifully submitting to parental demands yet harbor feelings of anger and resentment that are later manifest in feelings of loneliness or depression. Other children in the same family may perceive warm and indulgent parents as being less authoritative and have little regard for parental input. Relative to a more responsible sibling in the same family, who seems to require little oversight and direction, some children may take advantage of a parent's good nature by trying to get away with everything that they can. In essence, nonshared experiences that children in the same family have-in concert with individual genetic influences-often determine many different personality characteristics between siblings (e.g., Plomin et al., 1997; McGue, Sharma, \& Benson, 1996; Pike et al., 1996).

Environmental sources that operate to make siblings alike are referred to as shared effects. There is scientific evidence that shared effects stemming from parental modeling and encouragement of the same moral, religious, and political interests and values are as important, or even more important, than genes in creating similarities among siblings (e.g., Eaves, Eysenck, \& Martin, 1989; Hoffman, 1991, 1994a; Plomin, 1990). Even children who are treated differently can result in similar outcomes; for example, imposing more rules and limits for a difficult child may serve to foster more conformity so that he or she begins to behave in ways that are similar to those of his or her more conforming sibling. 
In summary, even though children may share constellations of genes and somewhat similar environments with their parents and siblings, their very natures can create different environmental niches that can contribute to declining resemblance over time (Wachs, 1999). Even identical twins who share the same genetic attributes do not turn out to be entirely similar due to different sets of experiences from which they build their environmental niches (e.g., Bouchard, Lykken, McGue, Segal, \& Tellegen, 1990; Farber, 1981). This suggests that parenting skills required to optimize social-communicative development may vary significantly from child to child.

\section{The Nurture Part of Nature}

Although it appears that children can exert considerable influence on their socialization environment (e.g., Bell \& Chapman, 1986), evidence is emerging to suggest that parenting behaviors can also enhance or diminish children's biological predispositions (Bronfenbrenner \& Ceci, 1994; Feldman, Greenbaum, \& Yirmiya, 1999). Recent findings support a conditional view of parenting that hinges on children's differential susceptibility to child-rearing influence (Belsky et al., 1998; Vandell, 2000). That is, parental influence in certain domains may be greater for some children than for others, according to their individual dispositions (Kochanska, 1993; Kochanska, Coy, \& Murray, 2001). For example, Kochanska (1997a) found that child compliance was associated with gentle, reasoning-oriented parental guidance for more temperamentally fearful-anxious children; however, compliance was linked to attachment security and responsiveness (e.g., shared cooperation, acceptance, sensitivity), and not to parental guidance, for non-fearful anxious children. This growing body of literature also suggests that parental sensitivity and nurturing involvement accompanied by firm limit setting and cohesive family relationships can diminish difficult and negative temperamental and externalizing behavior inside and outside of the home (e.g., Arcus \& Kagen, 1995; Engfer, 1986; Feldman et al., 1999; Fish, 1997; Hinshaw, Zupan, Simmel, Nigg, \& Melnick, 1997; Kandel \& Wu, 1995; Van den Boom, 1994; Woodward, Taylor, \& Dowdney, 1998). This has implications for intervention studies that are overviewed later.

There is further evidence to suggest that negative temperamental predispositions can either be enhanced or diminished in difficult children or be evoked in easier-to-raise children in the face of less parental responsiveness and involvement (e.g., Belsky, Fish, \& Isabella, 1991; Olson, Bates, Sandy, \& Lanthier, 2000; Wachs et al., 1993). Over two decades ago, Thomas and Chess (1977) proposed a "goodnessof-fit" model to describe how temperament and environmental pressures interact to affect children's development. Whereas good fit exists when child temperament and parenting styles are in harmony, poor fit results from dissonance between child responding and family environment (e.g., Patterson, Reid, \& Dishion, 1992). Interestingly, this hypothesis has only begun to be tested formally (e.g., Bates, Pettit, Dodge, \& Ridge, 1998; Kochanska, 1997a). Early findings suggest that a poor fit represented by punitive-parenting interactions with difficult temperament results in the production of internalizing (Denham, Auerbach-Major, Kochanoff, \& Queenan, 2002; Morris et al., 2002) and externalizing problem behaviors (Campbell, 1997; Paterson \& Sanson, 1999). Alternatively, nonpunitive restrictive parental control (e.g., prohibitions, warnings) is associated with lower levels of later externalizing in children who are difficult to manage earlier on (Bates et al., 1998).

In summary, numerous child-constitutional factors impact how sociable, internalizing, and externalizing behavior play out in children's social interactions. These 
factors can contribute to ways that parents respond to their children as well as be enhanced or mitigated by the child-rearing approaches that parents use (Bates et al., 1998; Patterson et al., 1992; Vuchinich, Bank, \& Patterson, 1992). We now consider specific parenting skills that seem to contribute to children's social-communicative competence in positive and negative ways.

\section{PARENTING SKILLS AND CHILDREN'S SOCIAL-COMMUNICATIVE COMPETENCE}

In terms of the relative influences of nature and nurture in the development of social and communicative competence, there is no single view of what aspects belong to nature and what belongs to nurture. In light of existing evidence regarding the influence of parenting skill and children's biological dispositions, three distinct perspectives have emerged:

1. Parents are not essential to children's development (e.g., Harris, 1998, 2000; Lytton \& Romney, 1991; Silverstein \& Auerbach, 1999);

2. An "average expectable" environment provided by parents is all that is needed (e.g., Rowe, 2002; Scarr, 1992);

3. "Optimal" rather than "good enough" parenting is essential for children's optimal development (e.g., Baumrind, 1993, 1997; Gottman \& DeClaire, 1997).

Evidence presented in our discussion thus far indicates the likelihood of considerable variation in children's behavior that may be due in part to factors in their biological development; however, this accounts for only part of the equation when it comes to social-communicative competence in children. In the research reviewed earlier, many scholars argue that parents do play a vital role in the development of childhood social skills and that "optimal" rather than just "good enough" parenting is important. As Baumrind (1993, 1997) and Wachs (2000) further pointed out, child outcomes associated with contrasting patterns of parenting vary considerably within, and not merely outside, normal ranges of development. Rather than dwelling extensively on the relative contributions of nature and nurture to each aspect of children's development, our view is that certain patterns of parenting are more and less healthy and adaptable to a child's nature, whatever it may be. We propose that parents reading a child's temperament and adjusting their behavior accordingly to maximize socialization influence is more likely to occur with some parenting styles than with others. We pick up on this theme after describing parenting styles.

\section{Parenting Styles}

Researchers have conceptually delineated parenting skills that are linked to children's social-communicative competence into styles and practices (Darling \& Steinberg, 1993). Styles are defined as "aggregates or constellations of behaviors that describe parent-child interactions over a wide range of situations and that are presumed to create a pervasive interactional climate" (Mize \& Pettit, 1997, p. 312). This climate likely moderates how receptive children are to certain parenting practices such as reasoning or limit setting when enacted in specific child-rearing contexts (cf. Baumrind, 1996; Grusec \& Goodnow, 1994; Kochanska, 1997b; Smetana, 1994). Our focus in this section is on parenting styles and the features that comprise them. 
Typologies and Features. Parenting styles have been conceptualized in a number of ways, two of which have been used in studying socialization (Darling \& Steinberg, 1993; Holden \& Miller, 1999; Maccoby \& Martin, 1983). The first approach is typological and focuses on the general patterns, organization, and climate of parenting. Using this approach, the parenting environment includes three categories, authoritative, authoritarian, and permissive (Maccoby \& Martin, 1983).

Also, researchers have used a dimensional approach in exploring socialization influence (Holden \& Miller, 1999). This approach is useful in desegregating distinctive modes of socialization so as to determine their linkages to child development outcomes. These include, but are not limited to, contrasting stylistic dimensions of power-assertive versus inductive, position-centered versus person-centered, parentcentered versus child-centered, punishment-oriented versus reason-oriented, and harsh-restrictive versus positive-nonrestrictive (e.g., Bronstein et al., 1996; Hart et al., 1990; Maccoby \& Martin, 1983).

Regardless of whether researchers use typological or dimensional approaches, three features of parenting that include many of the positive dimensions noted in the previous paragraph have been consistently used in describing competent parenting (Darling \& Steinberg, 1993). These include (a) the degree of parental support shown to a child (e.g., acceptance, affection, involvement, nurturance), (b) the degree of behavioral control placed on a child (e.g., limit setting, supervision, reasoning about and following through with consequences), and (c) the degree to which parents facilitate the development of psychological and emotional autonomy in children (e.g., choice giving, allowing child input into rule making, permitting the expression of ideas, avoiding intrusive behavior). More simply, these multidimensional features of parenting have been referred to as connection, regulation, and autonomy granting (Barber \& Olsen, 1997) and have recently been empirically packaged under the rubric of "authoritative parenting" for adolescent children (Gray \& Steinberg, 1999). These features are applicable to parents of young children in both the U.S. and mainland China, as demonstrated in recent research using multisample confirmatory factor analytic techniques (Wu et al., in press). Negative dimensions that include hostility (e.g., verbal and physical coercion), nonrestrictiveness, and other parentcentered approaches have been empirically derived as negative features delineating authoritarian and permissive parenting that we discuss later (Wu et al., in press).

Including parenting features within general typologies has allowed researchers to explore global patterns, such as linkages between authoritativeness and child or adolescent behavior (e.g., Glasgow, Dornbusch, Troyer, Steinberg, \& Ritter, 1997; Hart, Nelson, et al., 2000; Resnick et al., 1997; Steinberg, Lamborn, Darling, Mounts, \& Dornbusch, 1994). When unpackaged from the larger typologies, the functions that stylistic features of parenting serve can also be investigated (e.g., Darling \& Steinberg, 1993; Hart, Nelson, et al., 2000). Functions of stylistic features pertain to the immediate effects of consequences of parental behavior (e.g., getting a child to reflect on how his or her behavior impacts others or affects the child's long-term goals). Outcomes refer to long-term consequences for the child in relation to a particular feature. For example, more connectedness (patient, playful, sensitive parenting, particularly for fathers) has been associated with less childhood aggressive behavior, whereas less psychological autonomy granting has been linked to more childhood aggressive, internalizing and externalizing behavioral outcomes in the peer group (Hart, Nelson, Robinson, Olsen, \& McNeilly-Choque, 1998; Olsen et al., 2002). Reasoning-oriented regulation has been linked to greater sociable child behavior, empathy, adaptive social cognitions, and peer acceptance (e.g., Burleson et al., 1995; Hart, DeWolf, \& 
Burts, 1992; 1993; Krevans \& Gibbs, 1996), but not always to less childhood aggressive behavior (e.g., Hart, DeWolf, Wozniak, \& Burts, 1992; Pettit, Bates, \& Dodge, 1997).

Adaptability of Authoritative Parenting. One of the advantages of an authoritative style is that it is adaptable to individual child characteristics. It is not prescriptive. In essence, children appear to benefit from the flexible use of individualized features of child rearing that are conducted within the general framework of this stylistic pattern. As noted earlier, Kochanska (1997a) indicated that more anxious-fearful children benefit more from gentle, reasoning-oriented regulation, whereas non-fearful anxious children benefit more from the connectedness feature (shared cooperation, acceptance, sensitivity). Alternatively, more impulsive or resistive children become more manageable with greater rather than with lesser exposure to regulatory limit setting (e.g., prohibitions, warnings). This plays out in fewer externalizing outcomes both within and out of home settings over time (Bates et al., 1998). Nonpunitive regulation appears to be particularly salient for difficult children when accompanied by warm and supportive parenting that is reflected in the connection feature of the authoritative style (Hinshaw et al., 1997). These studies illustrate how the flexible use of authoritative-style features can provide the best fit for children with varying temperamental dispositions.

In essence, some children may require heavier doses of some authoritative features (e.g., regulation) than others, based on their temperamental dispositions; however, only a few studies have examined the moderating effects of parenting features on the associations between child temperamental predispositions and later adjustment (Collins, Maccoby, Steinberg, Hetherington, \& Bornstein 2000). Moreover, little is known about how and why some parents are better able than others to adjust their parenting styles according to child temperament in ways that maximize socialization influence. Obviously, balancing connection, regulation, and autonomy-granting across different sibling characteristics, developmental time frames, varying types of child transgressions, and disciplinary versus nondisciplinary contexts requires considerable skill, particularly in the face of competing demands (e.g., economic stress, fatigue, marital adjustments, time constraints). Reflecting this complexity, a recent meta-analysis indicates that even though parenting styles reflect enduring characteristics that persist over time, parents do modify aspects of child-rearing behavior in response to different children or to the immediate context as needed (Holden \& Miller, 1999). Little is known about how adaptable these adjustments are in meeting particular children's needs in ways that facilitate social-communicative competence, however.

\section{Authoritative Features and Children's Adjustment}

Although research investigating how parents adjust authoritative features to child nature are limited, there are scores of studies that link connection, regulation, and autonomy features of authoritative parenting to positive child outcomes (Ladd \& Pettit, 2002). In this section, we review literature that explicates how these features are associated with child social-communicative competence.

Connection Features. Warm and responsive parenting is often used to convey connection features of authoritative styles; however, researchers also describe connection in terms of acceptance, attentiveness, nurturance, patience, and sensitivity to and sympathy for children's feelings and needs (e.g., Wakschlag \& Hans, 1999). 
Warm and responsive parenting tends to promote lasting bonds with parents and "felt security" in children (Barnett, Kidwell, \& Leung, 1998; Lamb, Hwang, Ketterlinus, \& Fracasso, 1999). Secure attachments with parents function to facilitate the development of "working models" that provide expectations of positive reciprocal interpersonal outcomes from interactions with others (e.g., Elicker, Egelan, \& Sroufe, 1992; Cicchetti, Lynch, Shonk, \& Manly, 1992), better emotion regulation (Contreras, Kerns, Weimer, Gentzler, \& Tomich, 2000), and self-confidence for interacting with unfamiliar peers (e.g., Rubin et al., 2002). Warmth and responsiveness not only promotes secure attachments, but have been linked concurrently and longitudinally to more sociable outcomes and to fewer internalizing and externalizing problems with peers (e.g., Bronstein et al., 1996; Dumas, LaFreniere, \& Serketich, 1995; Russell \& Russell, 1996; Shaw, Keenan, \& Vondra, 1994). Attachment linkages, however, seem to be more important for children's close friendships rather than for enhanced relations with other peers (Schneider, Atkinson, \& Tardif, 2001). Warm, responsive, and accepting child rearing has also been found to prevent hostility, resentment, and anger in children (e.g., Hoffman, 1983; Lepper, 1981; Maccoby, 1983). Alternatively, hostile and rejecting parenting can be played out in hostile externalizing behavior with siblings, as well as with peers (e.g., MacKinnon-Lewis, Starnes, Volling, \& Johnson, 1997).

Connection also involves parents being companionable and playful with their children (Ladd \& Pettit, 2002). Research has documented that young children are less likely to be aggressive and more likely to be sociable and empathetic with peers if they have parents (particularly fathers) who display these qualities (e.g., Carson \& Parke, 1996; Chen, Liu, \& Li, 2000; Gottman \& De Claire, 1997; Hart, Nelson, et al., 1998; Lindsey \& Mize, 2000; Pettit, Brown, Mize, \& Lindsey, 1998). Alternatively, children with poorer peer conversational skills and subsequent peer-group behavior problems have less companionable fathers who express negative affect and dominate interaction and conversation in observed father-child dyadic interactions (Fagan \& Iglesias, 2000; Isley, O'Neil, Clatfelter, \& Parke, 1999; Isley, O’Neil, \& Parke, 1996).

Maternal connection to children is also important (e.g. Zhou et al., 2002). Research indicates that mothers who engage in mutually enjoyable activities with their children and assert less power over them are more likely to maintain a mutually responsive interaction style with their children throughout childhood (e.g., Kochanska, 1997b). These types of mutually enjoyable interactions, in which parents and children comply with each other's play suggestions, have been associated with advances in initiating play ideas, in attending to a play partners' desires and needs, and in responding to a partners' initiations in peer-group interaction (Lindsey \& Mize, 2000; Mize et al., 1995; Pettit \& Lollis, 1997). They appear to be a catalyst for establishing comfortable and emotionally fulfilling and connected relationships with others. It is possible that inherently sociable and conforming preschoolers in these studies were better able to evoke mutually responsive patterns of play with parents and peers; however, it seems more likely that parents attempting to connect with their children by being responsive rather than always directive teaches them something about the importance of reciprocity in forming lasting bonds with others.

Regulation Features. In contrast with connection, in which parent-child relationships are conceptualized as being more horizontal and symmetrical (almost peerlike), regulation is considered to be vertical and asymmetrical with the focus on parents instructing, correcting, teaching, or disciplining their children (Russell, 
Mize, \& Bissaker, 2002). Disciplinary situations, for example, require parents to move out of reciprocal role patterns (e.g., play and situations that allow for compromise) and exert authority in a more vertical fashion by placing clear and consistent limits on child behavior. The function of authoritative regulation is typically to persuade children to adopt parental views on certain issues and to regulate their behavior accordingly. This is typically done by setting limits, reasoning about rules and the consequences of misbehavior, reinforcing positive behavior, and following through with a judicious use of punishment as needed (Baumrind, 1996; Grusec, 2002; Patterson \& Fisher, 2002). How parents exert authority is important in less power-sharing contexts and can influence whether children feel respected as individuals and how well they internalize rules and become self-governing (Grolnick, 2003). Social-communicative outcomes also vary according to how parents enact regulative features in ways described in the following paragraphs (see also Hart, Newell, \& Sine, 2000).

Unlike coercive parents who administer harsh, arbitrary punishments (Ambert, 1997; Brody et al., 2001), studies indicate that authoritative parents are clear about rules and expectations and proactively explain reasons for setting them along with consequences for not meeting them (e.g., Baumrind, 1996; Pettit et al., 1997; 2001; Patterson \& Fisher, 2002). Parents who find ways to prevent child misbehavior rather than waiting for it to occur are more likely to have more compliant children and less frequent parent-child power struggles. (Chamberlain \& Patterson, 1995). In so doing, a premium is placed on communication as parents use disciplinary encounters more as teaching moments (rather than punishing moments) to help their children understand how to regulate their own behavior in positive ways without having to be controlled by arbitrary external rewards and punishments (Baumrind, 1996; Grusec \& Goodnow, 1994). Illustrative is research by Kuczynski and Kochanska (1995) in which toddlers of parents who emphasized "dos" rather than "don'ts" in communicative exchanges were found to exhibit lower levels of externalizing behavior at age 5 .

There are many times when limits that have been explained in advance by parents are violated. Authoritative parents are more likely to be firm and consistent when following through in nonpunitive ways with logical consequences that are tied to the misdeeds (e.g., calmly enforcing timeout when a child is angry and hurting others and then discussing alternative ways of dealing with anger; calmly showing up at a child's teen party when curfew is violated). Opportunities are then given for children to practice "trying it again," armed with new information about the whys and hows of enacting good behavior. As noted by Baumrind (1996), "Authoritative parents remain receptive to the child's views but take responsibility for firmly guiding the child's actions, emphasizing reasoning, communication, and rational discussion interactions that are friendly as well as tutorial and disciplinary" (p. 412).

This highlights the importance of reasoning and persuasion in regulatory encounters with children (e.g., "If you hit Johnny, he probably won't want to play with you anymore"). Although not required for every situation, consistent efforts to provide simple rationales that are often repeated eventually sink in and can function to win voluntary obedience even in 2- to three-year-old children (Hart, DeWolf, \& Burts, 1993). Numerous studies have documented positive ways that reasoning or induction with children (especially in advance of a problem) can help them willfully regulate their own behavior (e.g., Hoffman, 1994b; Kochanska, 1995; Krevans \& Gibbs, 1996). For example, parents who think ahead and predispose their young children before going into a store that "we are not buying treats to eat right now because we need lots of room in our tummies for dinner" are more likely to avoid temper tantrums in the checkout line. 
Burleson et al. (1995) suggested that such reflection-enhancing messages help children to understand situations "in a broadened way and see that courses of action should follow from consideration of relevant situational features and enduring values" (p. 62). For example, reasoning with children about consequences of their actions and possible solutions to interpersonal conflict helps focus children on the attitudes, feelings, perspectives, and needs of others (e.g., Bearson \& Cassel, 1975). Other-oriented reasoning, particularly on the part of mothers, has also been consistently linked to children's sociable (i.e., prosocial) behavior at home and with peers (e.g., Burleson et al., 1992, 1995; Hart et al., 1992; Krevans \& Gibbs, 1996; Pettit et al., 1998), particularly when accompanied by positive parental affect, prosocial modeling, and reinforcing statements (Grusec, Davidov, \& Lundell, 2002; McGrath, Wilson, \& Frassetto, 1995).

Reasoning-oriented regulation is associated with more adaptive and flexible parent interactions with children and facilitates more complex social problem-solving skills in them (Deković, Gerris, \& Janssens, 1991). This appears to enhance preschool and school-age children's abilities to accomplish social goals while simultaneously maintaining relationships with peers. For example, children of parents who employ inductive regulation are prone to envisioning friendly-assertive sociable behavior as leading to instrumental gains and enhanced relations with peers (Hart et al., 1990; Hart, DeWolf, \& Burts, 1992).

How children resonate to reasoning-oriented parental input depends on a variety of factors, including the age of the children, how "connected" their relationship is with the parent, and their ability to understand (Grusec \& Goodnow, 1994). For older children, reasoning can often come across as preachments and may provoke opposition if not carefully worded, particularly for more difficult children. Playing a "consultant role" often works better (Cline \& Fay, 1992). This involves reflective listening, using less directive "I" rather than more intrusive "you" statements, musing and wondering aloud about potential consequences and alternatives, and leaving more ownership for problem solving to the child. Communicating and regulating in this way requires considerable parental skill and flexibility but is far more likely to result in positive outcomes.

Finally, in addition to aversive consequences noted earlier, authoritative regulation can, in some cases, include a use of confrontation, reproofs, scolding, and prohibitions (without reasoning) when logically tied to a misbehavior (e.g., Bates et al., 1998; Kochanska, et al., 2001). Research suggests that when this is done firmly in the context of a warm and engaged parent-child relationship, children are more likely to comply to parental wishes; however, when coercively administered as a way to vent parental anger or brandish authority rather than to calmly emphasize an important message, conformance is less likely, and child resentment and hostility may ensue (Baumrind, 1996; Grusec \& Goodnow, 1994).

Autonomy-Granting Features. Children also benefit from making the choices that authoritative parents offer them and being allowed personal freedom in a variety of domains (e.g., Nucci \& Smetana, 1996; Nucci \& Weber, 1995). By developing decision-making skills and learning how to make personal decisions within limits that are acceptable to parents (e.g., allowing a child the option of taking the trash out in the evening or in the morning before school; asking if a child would prefer hot or cold cereal, etc.), children learn to become better self-regulators. In addition to selfregulation, supporting children's autonomy in this manner functions to help children view adults as providers of information and guidance rather than as deliverers of 
messages of control (Deci, Eghari, Patrick, \& Leone, 1994). Psychological control and authoritarian parenting (described in the next section) work against this important aspect of children's development (Barber \& Harmon, 2002; Olsen et al., 2002).

Even though the best of parents will, under difficult circumstances, lose patience and be demanding with children from time to time (e.g., Holden, Coleman, \& Schmidt, 1995), parents who are predominantly authoritative are more likely to interact with warmth and responsiveness, thereby allowing for more "give-and-take" in relationships with their children (e.g., Bronstein et al., 1996; Russell et al., 2002; Siqueland, Kendall, \& Steinberg, 1996). Parental communication is more likely to be open and nonjudgmental, with more emphasis on listening to understand rather than on talking (McFadyen-Ketchum, Bates, Dodge, \& Pettit, 1996). Respect for authority and independent thinking and feeling are valued, rather than viewed as being mutually exclusive. Research has indicated that children are more likely to be respectful to parents and others when there is this type of reciprocity and a degree of power-sharing in their relationships with parents (e.g., Dumas et al., 1995; Pettit \& Lollis, 1997).

Allowing young children to experience, value, and express their own thoughts, emotions, and desires is important in parent-child communicative interactions and for subsequent peer-group outcomes. Illustrative are studies showing that more socially competent children have mothers who are more likely to model power sharing and autonomy granting in horizontal relationships by communicating in ways that are positive, synchronous, and agreeable with children's views (e.g., Bronstein et al., 1996; Harrist, Pettit, Dodge, \& Bates, 1994; Putallaz \& Heflin, 1990). Black and Logan (1995) also recently demonstrated that autonomy granting and synchronous parent-child communications, as reflected in turn-taking style and utterance type, were related to more sociable child interactions with, and acceptance by, peers. However, nonresponsive communications with parents that did not allow for verbal give-and-take (e.g., irrelevant or simultaneous turns or turns that fail to leave time for a response following a request) have been linked to similar communication patterns with peers, internalizing and externalizing problems, and peer rejection (e.g., Fagan \& Iglesias, 2000; Kahen, Katz, \& Gottman, 1994).

In a related vein, when parents have been observed to dismiss or be judgmental about child views, to not tolerate differences of opinion, or to not allow input into family decision making, their preschool or school-age children have been found to be more prone to internalizing disorders (e.g., Olsen et al., 2002; Siqueland et al., 1996). Such displays of parental control that diminishes child expression appear to model a form of exclusionary behavior that has also been recently associated with preschool-age children enacting ostracizing, relationally aggressive tactics with peers (Hart, Nelson, et al., 2000).

Autonomy granting through "collaborative problem solving" (Crockenberg, Jackson, \& Langrock, 1996) and "joint decision making" (Lamborn, Dornbush, \& Steinberg, 1996) also plays out in potential conflict situations in which firm rules and restrictions are deemed less vital and parents model and encourage negotiation and compromise (e.g., allowing child's input into when to take the trash out). Finding ways to say yes more often than no to a child's request lends more credence when a parent has to say no in areas that require more vertical regulation. When children are given latitude for decision making in areas that matter less, they are more likely to conform to parental expectations that matter more (cf. Crockenberg et al., 1996; Kochanska, 1992; Kuczynski \& Lollis, in press; Russell et al., 2002). The resolution of conflict in collaborative decision making between parents and children is not all that dissimilar to ways that children learn to resolve 
interpersonal issues when trying to "partly get their way" in peer-group interactions (Bigelow, Tesson, \& Lewko, 1996; Crockenberg \& Lourie, 1996; Kochanska, 1992).

Developmental stages and child dispositions are also important to consider in autonomy granting. As children grow older and more mature, they can typically be granted more autonomy and a greater share in individual and family decision making (Baumrind, 1996). More spirited children, however, often require more creative regulation and limit setting coupled with opportunities for expressing individuality (e.g., Bates et al., 1998). Even for difficult children, positive psychological interventions that entail choice giving, encouragement of independence, and collaborative problem solving are less likely to provoke rebellion and oppositional behavior reflected in externalizing outcomes (e.g., Hinshaw et al., 1997). Recent evidence also suggests that more fearful and inhibited children's tendencies as reflected in reticent behavior noted earlier, may actually be exacerbated or maintained by parental overcontrolling and overprotective means that allow for less autonomy granting (e.g., Rubin, Nelson, Hastings, \& Asendorpf, 1999). This may account for why some children preclude themselves from social exploration (Rubin et al., 1998; Rubin, Cheah, \& Fox, 2001).

In summary, authoritiative parenting that includes balanced features of autonomy granting, along with regulation through limit setting, follow-through, and reasoning, as well as connection that is reflected in mutually responsive and satisfying relationships likely sets the stage for social and communication skills to thrive. As noted earlier, the degree to which these skills flourish are likely constrained or enhanced by biological and genetic factors that are inherent to each child. Connection, regulation, and autonomy features of authoritative parenting skill appear to be most effective when they are individualized and calibrated to provide the best fit to each child's unique set of strengths and limitations. These features are not mutually exclusive. Autonomy granting, for example, can foster connection in parent-child interactions. Connection may, in turn, be played out in children being more responsive to parent regulatory efforts.

\section{Coercive Interaction Styles}

The authoritative parenting style represents a challenging and creative endeavor that requires considerable flexibility, time, patience, and energy. The focus of authoritative approaches is more on teaching and preparing children than on regulating and controlling them (Hastings \& Rubin, 1999). Conversely, when parents are prone to employ "all-fits-one" controlling approaches across most child-rearing contexts and rely solely on punishment, isolation, or restriction, less creativity and flexibility is involved. Accordingly, authoritarian approaches provide fewer opportunities to meet individual child needs in ways that can optimize social and communicative competence. Like authoritative regulation, coercion functions to persuade children to adopt parental views on certain issues and to regulate their behavior accordingly; however, it is more likely to be administered in a harsh, arbitrary manner (Baumrind, 1996; Brody et al., 2001). Although coercion may often result in immediate compliance in children, it is suggested that it comes with a number of costs including the diminishing of children's abilities to learn how to regulate their own behavior from within (e.g., Gershoff, 2002; Rodgers, 1998). For example, parents who shut off their children's negative emotions in punitive or dismissive ways only invite more intense expressions that children have difficulty regulating with peers (Fabes, Leonard, Kupanoff, \& Martin, 2001). 
Persistent parenting that derides, demeans, or diminishes children by continually putting them in their place, putting them down, mocking them, or holding power over them via physical and verbal or psychologically controlling means are manifestations of coercive stylistic interactions. Research exploring outcomes for these coercive features indicates that such parenting appears to impede social and communication competencies in children (e.g., Stafford \& Bayer, 1993) and may be systemically maintained through mutually coercive parent-child exchanges (e.g., Dishion, Duncan, Eddy, Fagot, \& Fetrow, 1994; Vuchinich et al., 1992) that are driven by both child and parent aggressive behavior (Stoolmiller, Patterson, \& Snyder, 1997).

Physical and Verbal Coercive Features. A persistent use of physical and verbal coercion often takes place in homes in which there is a climate of hostility manifest by frequent spanking, yelling, criticizing, directing, and forcing and has been linked to many forms of childhood externalizing behavior directed toward peers that include relational and physical forms of aggression noted earlier (e.g., Hart, Nelson, et al., 1998, 2000; McFadyen-Ketchum, et al., 1996; Nix et al., 1999; Russell, Hart, Robinson, \& Olsen, in press; Shumow, Vandell, \& Posner, 1998; Pettit, Clawson, Dodge, \& Bates, 1996; Travillion \& Snyder, 1993). As noted earlier, coercive stylistic features tend to exacerbate already difficult temperamental dispositions in children. Hostile parenting of this nature has also been linked to peer-group rejection (e.g., Deković \& Janssens, 1992; Hart et al., 1990; Hart, DeWolf, Wozniak, \& Burts, 1992; Travillion \& Snyder, 1993). There is also evidence suggesting that associations between reciprocally hostile parent-child interactions and rejection by peers is mediated by aggressive behavior with peers (MacKinnon-Lewis et al., 1994).

In moderate forms with more normative samples, this style of parent-child interaction has been associated with children thinking they will get their way by using force with peers (e.g., Hart et al., 1990; Hart, DeWolf, \& Burts, 1992), particularly if parents model coercion as an efficacious means of resolving interpersonal conflict (see Coie \& Dodge, 1998; Crick et al., 1999; Crick \& Dodge, 1994; Pettit, Polaha, \& Mize, 2002; Parke et al., 1994). Interestingly, recent research suggests that the lack of connection (noted earlier in the authoritative style) for fathers and more coercion on the part of mothers are the most important predictors in the development of childhood aggressive behavior, at least in Russian parenting (Hart, Nelson, et al., 1998). Similar findings have recently been obtained in mainland China (Chen, Wang, Chen, \& Liu, 2002). Whether these patterns hold in all cultural settings in which coercive parental behavior is viewed as normative by children and adults is a point of debate in the literature (e.g., Baumrind, 1996; Bradley, Corwyn, Burchinal, McAdoo, \& Coll, 2001; Deater-Deckard \& Dodge, 1997; Stormshak, Bierman, McMahon, \& Lengua, 2000; Yang et al., in press).

Compared with the literature examining the effects of moderate but persistent levels of parental coercion, there is less certainty about whether milder forms and less frequent use of physical coercion lend themselves to similar problems noted above. There is a body of literature, for example, that suggests "nonabusive" spanking consisting of one or two mild slaps on the buttocks in limited situations (e.g., out-of-control behavior that poses danger to the child or others) can be beneficial for authoritative regulation as a last resort, but only for children between 2 and 6 years of age and when conducted sparingly in the context of a warm and responsive relationship (e.g., Baumrind, Larzelere, \& Cowan, 2002; Deater-Deckard \& Dodge, 1997; Larzelere, 1996; Larzelere, Sather, Schneider, Larsen, \& Pike, 1998). Alternatively, another group of studies support the notion that even though limited spanking to 
regulate behavior may immediately stop a child from misbehaving and willfully defying in the short term, it actually increases the likelihood of greater disobedience and antisocial behavior inside and outside the home later on (Gershoff, 2002; Strassberg, Dodge, Pettit, \& Bates, 1994; Straus, Sugarman, \& Giles-Sims, 1997; Stormshak et al., 2000). Additional research suggests that spanking is more likely to be enacted in anger (Holden et al., 1995).

More certain in the literature are findings associated with abuse. In more extreme samples of maltreated children (cf. Bolger \& Patterson, 2001; Deater-Deckard \& Dodge, 1997), severe forms of coercive parenting as manifested in extremely harsh and abusive treatment by adults appears to dysregulate and handicap children by altering their ability to successfully encode social cues and correctly interpret ambiguous peer provocations (Dodge, Bates, \& Pettit, 1990; Dodge, Pettit, Bates, \& Valente, 1995) lending itself to reactive aggression (Shield \& Chicchetti, 1998). Rather than being goal-oriented toward self-serving gains, reactive aggression is characterized by hostile attributional biases toward the aggressor and an angry and hypervigilant style of personal interaction (e.g., easily taking offense). Supporting research suggests that reactive aggressive children experience more extreme abusive family backgrounds when compared with proactive aggressive children (e.g., Schwartz et al., 1997). Similar findings concerning abusive parenting appear likely to hold across various cultural settings (e.g., Deater-Deckard \& Dodge, 1997).

Psychological Controlling Features. An emerging literature on psychological controlling parenting styles also suggests difficulties for children (e.g., Nelson \& Crick, 2002). Psychologically controlling behaviors include communicating disinterest in what a child is saying, invalidating or discounting a child's feelings, attacking a child in a condescending or patronizing way, or using guilt induction, love withdrawal, or erratic emotional behavior as means of control and manipulation (Barber \& Harmon, 2002). Psychological control, designed to manipulate children's psychological and emotional experience and expression, has been associated with "externalizing" and "internalizing" disorders in children of various ages and in diverse cultural contexts (e.g., Barber \& Harmon, 2002; Grotpeter \& Crick, 1996; Hart, Nelson, et al., 1998; Mattanah, 2001; Olsen et al., 2002; Pettit et al., 2001; Siqueland et al., 1996). It has also been linked to more internalizing behavior in temperamentally irritable children (Morris et al., 2002).

\section{Permissive Parenting}

Permissive-prone parents do exert some control over their children, but to a lesser degree than coercive and authoritative parents. They are less actively involved and may overindulge or neglect their children. They tend to avoid using their authority at all costs, are more tolerant of children's impulses (including aggression), encourage children to make their own decisions without providing parameters, and refrain from imposing structure on children's time (i.e., bedtime, mealtime, television watching). They also keep at a minimum restrictions, demands for mature behavior, and consequences for misbehavior (Maccoby \& Martin, 1983).

Research suggests that children raised by permissive parents may have greater difficulty respecting others, coping with frustration, delaying their gratification for a greater goal, and following through with their plans (Maccoby \& Martin, 1983). Unlike coercive parenting, in which child outcomes are predominately negative, permissive parenting produces mixed results. Outcomes associated with permissive 
parenting suggest that children are more sociable and tend to have a relatively low rates of internalizing problems (e.g., depression, anxiety); however, they do less well academically, are more defiant of authority figures, and exhibit a higher rate of externalizing behavior (e.g., Barber \& Olsen, 1997).

\section{Parenting Practices}

In our earlier discussion of parenting styles, we noted that the context created by style likely moderates how receptive children are to certain parenting practices. The concept of style captures an enduring manner in which mothers and fathers parent across "a wide range of situations that are presumed to create a pervasive interactional climate" (Mize \& Pettit, 1997). Practices, on the other hand, refer to particular efforts that parents undertake to accomplish specific goal-oriented tasks with children. Whether it be engaging in a mutually enjoyable activity to foster connection, reasoning about consequences to ward off misbehavior, spanking to punish for misdeeds, or providing choices to foster decision-making skills, parents may practice features of an authoritative or authoritarian style to accomplish their ends (see Mize, Russell, \& Pettit, 1998, p. 42). Sometimes, however, these features may be enacted with no specific goal in mind. When goal driven, authoritative parents will still be more likely to use connection, regulation, and autonomy-granting practices than will more coercive parents.

Parents may not intentionally act to foster children's peer relationship skills and social-communicative competence but accomplish precisely that end. For example, when reasoning about consequences for certain actions (e.g., picking flowers in the neighbor's flower garden) or playing a mutually enjoyable game with a child, parents are likely engaged with other goals in mind and are likely not considering how these interactions might be fostering social-communicative skills that carry over into peer-group interaction. Thus, these interactions may have indirect and unintentional positive implications in the peer arena; however, when unintentional style effects on peer competence are examined together with intentional practices used to foster social development, research indicates that both parenting style and practice make independent contributions to children's social-communicative competence (Mize \& Pettit, 1997).

We now consider parenting practices that parents intentionally employ to foster social competence in children. These practices can embody authoritative, coercive, or permissive stylistic features in how they are enacted. As will be seen, the function of each of the following practices is generally to foster social skills and social awareness in ways that result in sociable outcomes. There is considerable variation in whether these parenting practices are employed, however, as well as in ways stylistic features associated with these practices result in positive sociable or negative internalizing and externalizing outcomes for young children. Our discussion centers around ways that parental involvement in initiating peer contacts, supervising, or advising and consulting has been found to enhance sociability in young children.

Initiation Practices. Early research findings suggested that preschoolers with mothers who bridged between their child and playmates by fostering child-peer contacts had a larger number of playmates and more consistent play companions in their informal nonschool networks (Ladd \& Golter, 1988). Children with initiating mothers were also found to spend more time playing in peers' homes. This, in turn, was associated with better classroom adjustment and greater acceptance by peers 
(Ladd, Hart, Wadsworth, \& Golter, 1988). Other findings have linked parental initiations to child sociability in preschool classrooms (Ladd \& Hart, 1992), higher levels of peer acceptance for boys (Ladd \& Golter, 1988; Ladd \& Hart, 1992), and more stable and closer relationships among school-age friends (Krappman, 1989). Involvement, particularly on the part of mothers, is most effective when parents play a mediating role by "scaffolding" (e.g., verbally coaching about how to extend invitations to play) their child's peer engagements (Ladd \& Hart, 1992). Positive involvement in this manner reflects authoritative regulatory features.

Interestingly, recent findings suggest that mothers from a variety of cultural contexts are more prone to facilitate peer contacts if their children are perceived by teachers as being more socially inept (Hart et al., 1998). This raises the possibility that some parents may view peer associations as serving a remedial role for children with social skill deficiencies. They may adjust their parenting practices accordingly to provide meaningful associations with peers. Alternatively, evidence suggests that mothers who perceive their children to be more sociable, and who believe that child social skills are important, are more likely to play an active role in the further socialization of these competencies (e.g., Mize et al., 1995; Prinstein, 1997; Profilet \& Ladd, 1994). In summary, parents of young children who are involved in initiating peergroup interactions are likely to foster social competencies with peers. Parents also appear to adjust their parenting practices according to perceived social skill strengths and deficits seen in their children.

Supervision Practices. The strategies that parents use to supervise peer-group interactions and advise their children about peer-group issues have also been linked to child social-communicative outcomes with peers. Variations in these practices reflect both regulatory features of coercive parenting as well as positive regulatory and autonomy-granting features of authoritative parenting. For example, higher levels of maternal involvement, coupled with disruptive interventions and irrelevant or power assertive communications, are related to less socially skilled child behavior with peers (Mize et al., 1995). Alternatively, Finnie and Russell (1988) and Russell and Finnie (1990) obtained evidence suggesting that less intrusive (e.g., not taking direct charge of activities), group-oriented communication lends itself to children being more liked by peers (e.g., mothers making statements about what the other children are doing and encouraging their children to fit into the ongoing play). For older children, parental monitoring (tracking and surveillance) is important for reducing antisocial behavior; however, this practice is likely more effective when parental knowledge about a child's whereabouts and activities is based on voluntary child disclosure in a "connected" parent-child relationship than on parental intrusiveness (Kerr \& Stattin, 2000; Pettit et al., 2001).

Advising and Consulting Practices. How parents consult with their children about how to initiate friendships, manage conflicts, and identify solutions to interpersonal problems can go far in helping children negotiate their peer culture (cf. Flannagan, 1996; Flannagan \& Baker-Ward, 1996). There is some evidence to suggest that parental communication patterns are linked to variations in child abilities to communicate in socially contingent ways (e.g., Black \& Logan, 1995). It is also widely believed that these skills are enhanced or diminished in the context of reciprocal parentchild turn-taking communication activities. This provides a discourse structure from which children learn communicative rules of social engagement (Lamb, Ketterlinus, \& Fracasso, 1992; Stafford \& Bayer, 1993). 
For helping children learn how to negotiate their social world, parents often engage them in "decontextualized discussions" that can occur during dinner, after school, before bedtime, or during travel (Ladd, Profilet, \& Hart, 1992). Proficiently consulting with children entails considerable creativity and skill (e.g., Kuczynski, 1984; Ladd \& Le Sieur, 1995) and can be designed to prepare children to face future social dilemmas (e.g., discussing how to dissuade a bully) or can provide a sounding board for children's self-generated solutions (e.g., for how to mend a friendship). Research on parental advising and consulting practices has also been conducted in contrived laboratory and in peer-group settings. Parental engagement reflecting authoritative connection and autonomy-granting features has been positively associated with child sociability. Such engagement may include frequent conversations in which there is reciprocity in turn taking, high quality of advice that is relevant to resolving a peer issue, good listening skills, and warmth (Laird, Pettit, Mize, Brown, \& Lindsey, 1994; Profilet \& Ladd, 1996; Putallaz, 1987; Russell \& Finnie, 1990). Alternatively, coercive maternal consulting that is intrusive and focused on blaming the child for social shortcomings has been linked to childhood withdrawal from peers (Profilet \& Ladd, 1996).

Although the literature reviewed thus far seems to suggest that optimal parenting matters, there is considerable controversy about this conclusion. As noted earlier, there are varying views about how important parenting is to children's development. We now consider the view that parents don't matter and provide our response.

\section{DO PARENTS MATTER?}

Recent highly publicized reviews of research on parenting have concluded that there is no evidence that parenting in the home is related to ways children behave outside of the home (see Harris, 1995, 1998, pp. 75-77, 296, 330). Only genetics and peers matter in children's social development (Harris, 2002). This conclusion was made by drawing heavily on behavior-genetics research; Harris also cited-and misrepresents-a paper coauthored by the senior author of this chapter (Ladd et al., 1992). Harris's conclusion has been called into question by a number of scholars (Collins et al., 2000; Parke et al., 2002; Vandell, 2000; Wachs, 2000), with opportunities for rebuttal (e.g., Harris, 2000; Loehlin, 2001; Rowe, 2001). We now briefly consider several issues that extend already published work on the topic (see also Borkowski, Ramey, \& Bristol-Power, 2002; Hart, 1999).

First, in addition to other proported methodological flaws that are addressed elsewhere (Vandell, 2000), Harris denounces parenting research (2000, p. 712) for shared method variance problems (e.g., parents reporting on their own behavior as well as their child's); however, the majority of studies cited in this chapter (but overlooked in the Harris critiques) have used different informants for measuring parenting and peergroup behavior in ways that overcome this problem. Findings regarding parentingpeer-group linkages are remarkably consistent across studies that use observational or self-report measures of parenting and teacher or observational ratings of child social behavior (cf. Hart, Nelson, et al., 1998). Studies cited in this chapter (including Hart, Nelson, et al., 1998) often show stronger cross-contextual correlations (e.g., between home and school) than what Harris (2000, p. 718) credited.

Second, socialization research is criticized for not documenting the direction of effect (whether parents influence children or children influence parents). Yet at least 20 major longitudinal investigations conducted over the past decade were not considered in this critique (e.g., Bates et al., 1998; Booth, Rose-Krasnor, McKinnon, \& Rubin, 1994; Bronstein et al., 1996; Carlson, 1998; Kochanska, Aksan, \& Koenig 
1995; McGuire, Dunn, \& Plomin, 1995; Pettit \& Bates, 1989). Results clearly indicate that parents have lasting influence on children's behavior outside of the home, as reflected in independent measures of parenting and peer interaction (e.g., Elicker et al., 1992; McFadyen-Ketchum et al., 1996; Pettit et al., 1996, 1997; 2001).

Although claims of causation running from parent to child are not entirely conclusive (cf. Baumrind et al., 2002; Cowan \& Cowan, 2002; Nix et al., 1999), these investigations do suggest that direction of effect can go from parent to child, at least in terms of parental influence maintaining child behavioral patterns or bidirectional parentchild interactive processes that play out in peer relations (e.g., Bradley et al., 2001; Dodge, Pettit et al., 1995; Heller \& Baker, 2000; Loeber \& Dishion, 1983; Kochanska \& Murray, 2000; Shaw et al., 1994; Sroufe \& Fleeson, 1986; Zhou et al., 2002). This in no way discounts the perspective that the effectiveness of parenting can vary for children with different dispositions as we noted earlier (cf. Vandell, 2000). We have cited ample evidence suggesting that parent behaviors likely enhance or mitigate child dispositional tendencies towards sociability, internalizing, and externalizing both inside and outside of the home. Taken together, this literature contradicts the view that parents only differentially respond to varying child dispositions and have no influence on their behavior outside of the home (see Harris, 1998, p. 48; Harris, 2000, pp. 712, 715, 717).

Third, Harris (1998) criticizes parenting research by suggesting that socialization effects can only be artificially contrived in diverse rather than in homogenous samples that include, for example, similar socioeconomic groupings of parents and children rather than mixed socioeconomic groupings. Numerous studies conducted in homogenous groupings discount this claim (e.g., Barber \& Harmon, 2002; Baumrind, 1993, 1997; Hart, DeWolf, Wozniak, \& Burts, 1992; Hart, Nelson, et al., 1998; Shumow et al., 1998; Wachs, 2000). Although there are some exceptions (Deater-Deckard \& Dodge, 1997; Stormshak et al., 2000), research consistently shows that coercive parenting is associated with similar types of child peer-group behavior problems in middle-class samples as well as in disadvantaged samples (e.g., Hart, DeWolf, \& Burts, 1992; Hart et al., 1990).

Fourth, drawing primarily from behavioral-genetic research, Harris argued that genetics and peers matter, not parents. Notwithstanding limitations in behavioralgenetic methodology (Collins et al., 2000), it should be kept in mind that results from classic designs using this approach can only say that many sibling similarities may be primarily due to genetics. Sibling similarities in behavioral adjustment are linked to shared parental treatment, even after controlling for genetic similarity (Deater-Deckard, 2000); however, the direction of effect leading from child genetics to parenting or vice versa cannot be ascertained in these designs. Nonshared environmental effects show up in all behavioral-genetic studies. When differences in parental behavior toward siblings covary with sibling differences in behavioral adjustment, it is still unknown if sibling behavioral differences are a cause or consequence of parental differential treatment. As Deater-Deckard (2000) pointed out, root causes of sibling differences are typically unspecified in behavioral-genetic research because it is difficult to determine whether they result from shared (e.g., different child perceptions of and reactions to the same parenting) or from nonshared environmental sources (e.g., differential parental treatment). Thus, behavioral-genetic research cannot say whether parents matter or not. These studies can only indicate that many things that parents do similarly with siblings often do not make siblings turn out the same. In critiques of parenting research, sibling differences reflected in nonshared effects have been attributed only to forces outside the family, namely peers (Harris, 1998, 2000, 2002). Pike (2002) noted that these claims were made in the 
absence of studies that consider whether peer-group characteristics, like parenting styles, might also correspond with genetic influence. Contrary to the assumption that only peers matter beyond genetics, this leaves ample room for the importance of parents as contributors to child outcomes (cf. Parke et al., 2002). Indeed, there is convincing data to suggest that both parents and peers matter in children's socialcommunicative competence (e.g., MacKinnon-Lewis, Rabiner, \& Starnes, 1999; Parke et al., 2002; Sroufe, Egeland, \& Carlson, 1999; Vandell, 2000).

Finally, there is evidence from intervention studies indicating that parents do matter. Although these studies do have methodological limitations (see Borkowski, et al., 2002; Harris, 2000), several investigators have used experimental designs, including random assignment to treatment groups in which parenting skills have been modified (see Vandell, 2000). A number of these studies have demonstrated subsequent changes in child behavioral-communicative outcomes within and outside of the home (see Tremblay et al., 1992; Webster-Stratton \& Hammond, 1997; Yoshikawa, 1994). As will be seen in the next section, even though not all studies have reached this conclusion, there is available supporting evidence.

\section{INTERVENTIONS FOR PROMOTING SOCIAL-COMMUNICATIVE SKILLS IN CHILDREN AND PARENTS}

We have reviewed how parents' socialization and communication practices and styles are linked to children's social and communicative competence; however, much of the parent intervention literature does not focus on children's social or communicative competence as outcome variables, concentrating instead on academic aspects of children's development. The purpose of this section is to examine recent intervention research, with an eye toward helping interventionists consider a number of issues in designing future programs that could enhance child outcomes and parenting skills in ways that promote social-communicative competence. We first consider the aims and elements of successful interventions and the need for quality intervention studies. This is followed by a summary of conceptual and methodological issues in intervention studies. We conclude by discussing selected intervention programs that have particular relevance in promoting social-communicative competency skills.

\section{Aims and Elements of Successful Interventions}

It is common for developers of interventions to focus on supportive parenting, as reflected in features of authoritative styles, which can foster children's social competence, self-esteem, self-reliance, adaptability, and school achievement (Bronstein et al., 1998). Many of the programs available reflect efforts to operationalize this information into practical interventions designed to help parents and children who are struggling.

Interventions have increasingly targeted different relationships within the family system, such as the marital dyad, mother-child dyad, and father-child dyad (Cowan, Powell, \& Cowan, 1998). Other parent education programs provide a variety of emotional, informational, and instrumental support to families, as well as striving to develop family ties to formal and informal support networks. Such networks have been found to have an indirect effect on children's behavioral development through their effect on parenting (Yoshikawa, 1994). 
Perceptions, expectations, and beliefs also appear to be important factors contributing to decisions about and success in participating in a training program or intervention activity (Powell, 1998). For example, researchers indicate that the most common factor preventing parents' participation in intervention or education programs was the belief that the program would not make a difference for their child (Powell, 1998).

Yoshikawa (1994) identified the following common elements of successful interventions: (a) produces effects on multiple risk factors, such as ineffective parenting or child behavior; (b) includes ecological, multiple-setting designs, providing support in multiple settings, such as peer groups, schools, and families; (c) involves urban, low-income populations; (d) continues for at least 2 years; and (e) is implemented during the child's first 5 years of life. Unfortunately, many interventions do not meet these criteria.

These elements support the aim of early family support and education, facilitating the optimal development of the child and family (Yoshikawa, 1994). A holistic approach-parent, child, and context—provides the most effective means of positive intervention and the enhancement of social-communicative skills.

\section{The Need for Quality Intervention Approaches}

Cowan et al. (1998) present four explanations that proponents use to justify a need for parent and family interventions. First, parents are central to children's development, but they lack natural competence and need direction. Second, traditional parenting practices may not be effective and need revising in light of scientific findings. Third, there is a need to reinstitute traditional family structures and practices that have been shown to shore up families in light of contemporary family disarray. Fourth, families need support in coping with the stressors of modern life (e.g., financial, medical, child-rearing concerns, drugs, and negative peer influences).

To address these needs, a diverse and considerable body of intervention-related studies and programs has been developed. A range of programs is available; however, empirically validated programs are few, and the programs that have been widely disseminated are those with the least evidence about their effectiveness (Cowan et al., 1998).

\section{Conceptual and Methodological Issues in Intervention}

Reviews of the parent-child intervention literature conducted over the past decade have considered the strengths and weaknesses of various intervention approaches and have yielded different conclusions (e.g., Bryant, Vizzard, Willoughby, Kupersmidt, 1999; Cowan et al., 1998; Howrigan, 1988; Mash \& Barkley, 1998; McFadyen-Ketchum \& Dodge, 1998; Powell, 1994; White, Taylor, \& Moss, 1992; Yoshikawa, 1994). A number of reviews have concluded that early childhood interventions show promise in preventing delinquency later on (Farran, 1990; Farrington et al., 1990; Kazdin, 1990; Zigler, Taussig, \& Black, 1992). Powell's (1994) evaluation of family support and education programs identified "mixed" as well as "promising directions." Others, however, have questioned the usefulness or effectiveness of interventions due to methodological problems, limitations in evaluation methodologies, and mixed results of program effects (e.g., Eddy, Dishion, \& Stoolmiller, 1998; Gorman \& Balter, 1997; Harris, 2000; White, Taylor, \& Moss, 1992). Thus, the opinions regarding the efficacy of early intervention programs range from optimism to despair. 
In highlighting less optimistic views of intervention effectiveness, White et al. (1992) posited that in previous well-controlled studies, the "almost universal perception" regarding the benefit of parent involvement and education has not been found to be valid. Reasons for the null effects may include (a) using parents as supplemental interveners with their children, (b) poor implementation strategies, and (c) being at the beginning stages of measuring the effects of parent involvement and education activities on parents and family members. These problems appear to be exacerbated by the lack of agreement about the definition of parent involvement and education (Galper, 1998).

Recently, Cowan et al. (1998) identified a number of methodological standards that will help to overcome design and measurement flaws in existing intervention studies. These standards include the following:

samples larger than 10 to 15 families; inclusion of fathers as well as mothers; inclusion of no-treatment or alternative-treatment controls; random assignment to experimental conditions, and multi-measure, multimethod assessments that include parent self-reports, parents' reports about children, observations of parents' behavior, and independent assessments by both teachers and researchers of outcomes such as children's cognitive and social competence and behavior problems. . . [and] data from children's perspective. (p. 54)

Cowan et al. lamented the fact that recent literature reviews show that "only a handful of studies" meet more than one or two of these criteria.

\section{Specific Parent-Child Focused Intervention Programs}

In this section, we offer an overview a few selected intervention programs developed in the past decade that have been found to enhance social-communicative skills or diminish negative behavioral and communication patterns (see also Baumrind et al., 2002). This narrowing of focus necessarily eliminates many interventions that enhance academic and cognitive skills, as well as programs that focus exclusively on changing parental behavior (e.g., Smith, Perou, \& Lesesne, 2002). In addition, programs that primarily involve contexts beyond the family (such as schools) are not included even though they often have a parent intervention component (for example, Conduct Problems Prevention Research Group, 1999; Olweus, 1994; Reynolds, 1994). For a current review, see Eisenberg and Valiente (2002).

The role of parenting in child behavioral outcomes has been researched extensively by Patterson (1982) and his colleagues (Patterson et al., 1992; Patterson, Dishion, \& Chamberlain, 1993) at the Oregon Social Learning Center (OSLC). This seminal parenting training effort has focused on replacing negative parent-child interactions with more positive ones, so that children will learn to use positive ways to deal with others (see Dumas, 1989; McMahon \& Wells, 1989; McFayden-Ketchum \& Dodge, 1998).

Results from the OSLC program suggest that interventions targeting parenting skills can help diminish aggressive behavior in children as reciprocally coercive chains of parent-child interaction are broken (Patterson \& Fisher, 2002). In random assignment studies, interventions that are successful in reducing child antisocial behavior require that parents be trained to consistently reinforce sociable behavior and to use punishments that are authoritatively regulating in nature (rather than authoritarian), such as implementing natural or logical consequences (Forgatch \& Patterson, 1989). 
The basic assumption is that using more effective (authoritative) regulations directly reinforces prosocial behaviors and reduces the reinforcement for deviant behavior (Stoolmiller et al., 1997).

Tremblay et al. (1992), using an intervention model based on OSLC, taught a series of social-communicative skills to parents over the course of 2 years. Compared with control peers, treatment children showed lower levels of teacher-rated externalizing, higher levels of school achievement, and higher levels of overall teacher- and peerrated adjustment, as well as less self-reported delinquent behavior (cf. McFaydenKetchum \& Dodge, 1998).

Another intervention project that focused parents on different aspects of authoritative skills in working with their children during the early childhood years comes from the Houston Parent-Child Development Center. The first year of the project, paraprofessionals visited mothers from low-income Mexican American families 25 times for 1.5-hour sessions, in which they taught about child development, parenting skills, and the home as a learning environment. Siblings and fathers also participated in several weekend sessions. The second year, mother and child came to the project center 4 days a week and participated in classes on child management, child cognitive development, family communication skills, and other topics. The experimental-group mothers were more likely to be affectionate and responsive with their children, as well as less punishing than control-group mothers as a result of the intervention. In 5to 8-year follow-ups, their children were rated by teachers as being less aggressive, impulsive, and disruptive when compared with control-group children (Johnson \& Walker, 1987).

Draper, Larsen, and Rowles (1997) evaluated a parent education program designed to teach parents general principles of developmentally appropriate childrearing practices. Lessons included topics such as positive parent-child relationships, effective family discipline and communication, and individual and age differences in children. Instructional content was conveyed in one of three ways: reading lesson materials, listening to cassette tapes, or receiving instruction via home visits. The goal was to have a positive effect on the emotional climate in the home by focusing on family communication, organization, and the exercise of supportive leadership, as well as developmentally appropriate parenting emphasizing authoritative connection and autonomy granting in parent-child interactions. In assessments conducted at the end of the program, Draper et al. found that compared with control parents, program participants were less likely to engage in conflict and more likely to take a supportive leadership role (lowered task expectations, focusing more on process than outcome) in various puzzle-solving tasks with their children. Preschoolers in participating families showed better social skills than children in nonparticipating families. This was due in part to reductions in family conflict.

Webster-Stratton and Hammond (1997) compared the effects of three types of interventions (parent training, child training, parent and child training) on children with early-onset conduct problems. In the "child training" group, children between the ages of 4 and 7 years old who had been diagnosed with early-onset conduct problems attended 22 two-hour sessions in which they watched vignettes of children coping with interpersonal difficulties normally encountered by children their age. Therapists discussed each vignette, eliciting children's reactions, ideas, and questions. In the "parent training" group, parents of children with early-onset conduct problems met weekly for 22 weeks with a therapist for 2-hour sessions, in which they viewed vidoetaped programs on parenting and interpersonal skills. A third group received both child and parent training. After completion of the intervention, children's 
behavior was compared with that of a control group. Results indicated that child training combined with parent training was superior to either one alone. Combined parent and child training resulted in improved parent-child interaction, improved behavior at home, and better conflict management and social problem-solving skills. One-year follow-up assessments showed the improvements had been maintained.

Bronstein et al.'s (1998) Aware Parenting intervention with lower income families builds on a model that includes five components: support, attentiveness, responsiveness, guidance, and receptivity to emotion. A couple's group and a single mother's group met weekly for 2-hour sessions over 11 consecutive weeks. Each session focused on one of the components and included facilitators sharing information, group discussion, and instructional exercises, such as role playing. Among other things, the mothers who attended the education and support groups reported positive changes in parenting, including higher levels of responsiveness, guidance, and receptivity to emotion, as well as improved communication. Those parenting changes were reflected in positive child behavioral outcomes over time, including treatment-condition children making a more positive adjustment to middle school compared with control-condition children, who experienced a decline in adjustment.

McNeil, Capage, Bahl, and Blanc (1999) assigned 32 families of young children who had been referred for treatment of disruptive behavior to either a treatment or wait-list control group. Parents in the treatment group received a 12-week parenting program in which therapists taught them skills that promoted prosocial behavior, as well as authoritative discipline strategies. The behavior of children in the treatment group improved over the 3-month treatment period, whereas the behavior of children in the control group remained problematic. In addition, at the end of the intervention, treatment parents scored significantly lower on the parenting stress index than control parents.

Sanders, Montgomery, and Brechman-Toussaint (2000) used a 12-episode television series as an intervention and evaluated its impact on disruptive child behavior and family adjustment. Participants were randomly assigned to either a wait-list control group (WL) or to watch the television series (TV), which covered topics such as authoritative parenting strategies that could be used to address common behavioral problems, teaching children new skills, and helping them master difficult tasks. Each segment was of approximately 20 to 30 minutes' duration and parents also received written self-help information sheets. Parents in the TV condition, when compared with the WL group, reported significantly lower levels of disruptive child behavior and higher levels of perceived parenting competence immediately following intervention. All postintervention effects were maintained at 6-month follow-up.

Cowan et al. (1998) noted that many intervention programs focus on teaching discipline skills to parents of children who are aggressive, whereas few programs focus specifically on how to help parents who have children who are anxious, depressed, withdrawn, or manifest other internalizing problems. One exception is recent research completed by Spence, Donovan, and Toussaint (2000), who conducted an intervention for children aged 7 to 14 years who had a principal diagnosis of social phobia. Children were randomly assigned to one of three groups: waiting-list control (WLC), cognitive-behavior therapy (CBT), or CBT plus parent involvement. The CBT program involved social skills training, social problem solving, positive self-instruction, cognitive challenging, and graded exposure to social situations. The intervention involved 12 one-hour sessions, conducted weekly, followed by two booster sessions, one at 3 months and one at 6 months after course completion. Each treatment session was structured to be age-appropriate, was followed by a half-hour social practice "games" session, and included a weekly homework task. 
Parents were taught to authoritatively prompt, model, and encourage appropriate social skills. Compared to control children, significantly fewer children in both treatment conditions retained a clinical diagnosis of social phobia. There was a reduction in problem social skills and general anxiety among children in both treatment groups, which was retained at the 12-month follow-up.

\section{Summary and Implications}

Interventions, such as those mentioned above, assist parents and children in the development of social and communication skills that lead to positive outcomes; however, they face numerous challenges at multiple levels. The contributions of intervention research and several of the programs highlighted here are significant and worth noting: the behavior of parents and children often changed in positive ways and the intervention studies went beyond correlational studies in informing us about mechanisms of change (Cowan et al., 1998).

Some long-term outcome data that include externalizing and internalizing child behaviors indicate that interventions focused on both parent-child interactions at home and on teacher-child and peer-child interactions in the school may produce the greatest long-term gains (McFadyen-Ketchum \& Dodge, 1998; Yoshikawa, 1994). Consequently, effective intervention programs must look to the whole child and consider the contexts of family, parents, school, peers, and each unique individual as potential objects of intervention activity.

In identifying directions for future studies, Cowan et al. (1998) discussed specific research questions regarding interventions that remain unanswered including the following: (a) Is work with parents essential to affecting children's outcomes? (b) What is the role of parents' and children's gender in parenting intervention?

(c) What are the mechanisms of change in parenting interventions? (d) What is the most effective parenting intervention for a specific family? and (e) How long do intervention effects last?

In answering these and other questions, a need exists for long-term, multiple follow-up assessments in multiple settings and continued research on effective, comprehensive, practical intervention approaches that will enhance both child and parent social and communication skills which, in turn, may improve relationships, diminish problem behaviors, and promote positive outcomes. Parent-child social communicative intervention seems to be a process that is logically, even intuitively beneficial, yet it clearly warrants more rigorous scientific attention from family, developmental, and communication researchers.

\section{GENERAL SUMMARY}

Children vary considerably in their expression of social-communicative competence. Research has provided an understanding of how socially skilled children are better able to read the emotional states of others, have appropriate expectations for how their behavior will impact peers in interpersonal conflict situations, and communicate in socially contingent and relevant ways during social interaction. Children lacking these skills are more likely to exhibit externalizing or internalizing difficulties in peer group interactions. Molecular genetics, behavioral genetics, temperament, and physiological research have provided clues as to possible biological predispositions that lend themselves to the expression of more or less socially skilled behavior.

How biological propensities play out in social behavior depends in part on interactions with the child-rearing environment. Children with varying dispositions may 
evoke unique responses from parents and seek out social experiences that best fit their constitutional natures. They may also respond to parenting behaviors according to how experiences are filtered through their individual perceptions. Thus, parental influence has been generally thought to operate within the constraints of child genetics; however, more recent evidence suggests that parenting behaviors can serve to enhance or diminish children's biological predispositions. The temperament and disposition of each child can vary significantly within the same family, and consequently the relationship between parents and different siblings is dynamic and unique, with each individual responding to and modifying the behavior of the other (cf. Bell \& Chapman, 1986; Dumas \& LaFreniere, 1995; Lytton, 1990; Nix et al., 1999; Patterson, Reid, \& Dishion, 1992). Just as child nature can evoke different socialization practices on the part of parents, parents can also proactively serve to enhance or diminish positive or negative social-communicative characteristics in children, depending on the styles and practices that they employ. Reciprocal transactions between parent and child likely play out for better or worse in children's sociable, internalizing, and externalizing behavior (e.g., Dumas \& LaFreniere, 1995; Kandel \& Wu, 1995). Discovering and maintaining the right fit between parenting and individual child temperament is one of the most challenging aspects of child rearing. It requires considerable flexibility and creativity.

The most flexible approach to parenting is the authoritative style. Parents who skillfully read their child's predispositions strive to tailor connection, regulation, and autonomy granting features across developmental time frames, varying types of child transgressions, and disciplinary versus nondisciplinary contexts according to individual child needs. By adjusting to individual child characteristics and engaging in specific practices designed to foster social and communicative competence (e.g., initiating peer contacts, advising and consulting), research suggests that parents are more likely to help their children become more socially skilled in peer group interaction. Children of parents who do so are less likely to display internalizing and externalizing difficulties during social interactions with peers. Alternatively, all-fits-one approaches to parental control exemplified by coercive and psychologically controlling parenting styles increase the likelihood that children will experience social and communicative deficits.

Contrary to recent views suggesting that parents matter little in children's development beyond the influence of genetics and peers, there is ample evidence to suggest that genetics, parents, and even peers all play vital roles in the development of child social and communicative competence. The results of a number of recent intervention studies, for example, indicate that when negative parenting behavior is modified to correspond with features of authoritative styles, child behavior inside and outside the home can change accordingly in positive ways. Taken together, the research reviewed herein suggests that parenting represents a complex interplay between nature and nurture. How parents practice features of authoritative, coercive, and permissive styles in interactions with their children can have far-reaching implications for child adjustment in peer group interactions.

\section{REFERENCES}

Aboud, F. E., \& Mendelson, M. J. (1996). Determinants of friendship selection and quality: Developmental perspectives. In W. M. Bukowski, A. F. Newcomb, \& W. W. Hartup (Eds.), The company they keep: Friendship in childhood and adolescence (pp. 87-112). New York: Cambridge University Press. 
Adalbjarnardottir, S. (1995). How school children propose to negotiate: The role of social withdrawal, social anxiety, and locus of control. Child Development, 66, 1739-1751.

Ambert, A. (1997). Parents, children, and adolescents: Interactive relationships and development in context. New York: Haworth Press.

Arcus, D., \& Kagan, J. (1995, March). Temperamental contributions to social behavior. Symposium presentation Society for Research and Child Development, Indianapolis, IN.

Asendorpf, J. (1990). Development of inhibition during childhood: Evidence for situation specificity and a two-factor model. Developmental Psychology, 26, 721-730.

Asendorpf, J. B. (1993). Beyond temperament: A two-factorial coping model of the development of inhibition during childhood. In K. H. Rubin \& J. B. Asendorpf (Eds.), Social withdrawal, inbibition, and shyness in childhood (pp. 265-289). Hillsdale, NJ: Lawrence Erlbaum Associates.

Asher, S. R., Parker, J. G., \& Walker, D. L. (1996). Distinguishing friendship from acceptance: Implications for intervention and assessment. In W. M. Bukowski, A. F. Newcomb, \& W. W. Hartup (Eds.), The company they keep: Friendship during childhood and adolescence (pp. 366-405). New York: Cambridge University Press.

Barber, B. K., \& Harmon, E. L. (2002). Violating the self: Parental psychological control of children and adolescents. In B. K. Barber (Ed.), Parental Intrusive parenting: How psychological control affects children and adolescents (pp. 15-52). Washington, DC: American Psychological Association.

Barber, B. K., \& Olsen, J. A. (1997). Socialization in context: Connection, regulation, and autonomy in the family, school, and neighborhood, and with peers. Journal of Adolescent Research, 12, 287-315.

Barnett, D., Kidwell, S. L., \& Leung, K. H. (1998). Parenting and preschooler attachment among lowincome urban African American families. Child Development, 69, 1657-1671.

Bates, J. E., Pettit, G. S., Dodge, K. A., \& Ridge, B. (1998). Interaction of temperamental resistance to control and restrictive parenting in the development of externalizing behavior. Developmental Psychology, 34, 982-995.

Baumrind, D. (1993). The average expectable environment is not good enough: A response to Scarr. Child Development, 64, 1299-1317.

Baumrind, D. (1996). The discipline controversy revisited. Family Relations, 45, 405-414.

Baumrind, D. (1997). Necessary distinctions. Psychological Inquiry, 8, 176-229.

Baumrind, D., Larzelere, R. E., \& Cowan, P. A. (2002). Ordinary physical punishment: Is it harmful? Comment on Gershoff. Psychological Bulletin, 128, 580-589.

Bearson, D. J., \& Cassel, T. Z. (1975). Cognitive decentration and social codes: Communicative effectiveness in young children from different family contexts. Developmental Psychology, 11, 29-36.

Bell, R. Q., \& Chapman, M. (1986). Child effects in studies using experimental or brief longitudinal approaches to socialization. Developmental Psychology, 22, 595-603.

Belsky, J., Fish, M., \& Isabella, R. (1991). Continuity and discontinuity in infant negative and positive emotionality. Developmental Psychology, 27, 421-431.

Belsky, J., Friedman, S. L., \& Hsieh, K. (2001). Testing a core emotion-regulation prediction: Does early attentional persistence moderate the effect of infant negative emotionality on later development? Child Development, 72, 123-133.

Belsky, J., Hsieh, K., \& Crnic, K. (1998). Mothering, fathering, and infant negativity as predictors of boys' externalizing problems and inhibition at age 3 years: Differential susceptibility to rearing experience? Development and Psychopathology, 10, 301-319.

Bigelow, B. J., Tesson, G., \& Lewko, J. H. (1996). Learning the rules: The anatomy of children's relationships. New York: Guilford Press.

Black, B., \& Logan, A. (1995). Links between communication patterns in mother-child, father-child, and child-peer interactions and children's social status. Child Development, 66, 255-271.

Bolger, K. E., \& Patterson, C. J. (2001). Developmental pathways from child maltreatment to peer rejection. Child Development, 72, 549-568.

Booth, C. L., Rose-Krasnor, L., McKinnon, J., \& Rubin, K. H. (1994). Predicting social adjustment in middle childhood: The role of preschool attachment security and maternal style. Social Development, 3, 189-204. 
Borkowski, J. G., Ramey, S. I., Bristol-Power, M. (Eds.). (2002). Parenting and the child's world: Influences on academic, intellectual, and social-emotional development. Mahwah, NJ: Lawrence Erlbaum Associates.

Bouchard, T. J., Jr., Lykken, D. T., McGue, M., Segal, N. L., \& Tellegen, A. (1990). Sources of human psychological differences: The Minnesota study of twins reared apart. Science, 250, 223-228.

Bradley, R. H., Corwyn, R. F., Burchinal, M., McAdoo, H. P., \& Coll, C. G. (2001). The home environments of children in the United States Part II: Relations with behavioural development through age thirteen. Child Development, 72, 1868-1886.

Brinton, B., \& Fujiki, M. (2002). Social development in children with specific language impairment and profound hearing loss. In P. K. Smith \& C. H. Hart (Eds.), Blackwell handbook of childbood social development (pp. 588-603). Oxford, England: Blackwell.

Brody, G. H., Ge, X., Conger, R., Gibbons, F. X., Murry, V. M., Gerranrd, M., \& Simons, R. L. (2001). The influence of neighborhood disadvantage, collective socialization, and parenting on African American children's affiliation with deviant peers. Child Development, 72, 1231-1246.

Bronfenbrenner, U., \& Ceci, S. J. (1994). Nature-nurture reconceptualized in developmental perspective: A bioecological model. Psychological Review, 101, 568-586.

Bronstein, P., Duncan, P., Clauson, J., Abrams, C. L., Yannett, N., Ginsburg, G., \& Milne, M. (1998). Preventing middle school adjustment problems for children from lower-income families: A program for aware parenting. Journal of Applied Developmental Psychology, 19, 129-152.

Bronstein, P., Duncan, P., D’Ari, A., Pieniadz, J., Fitzgerald, M., Abrams, C. L., Frankowski, B., Franco, O., Hunt, C., \& Oh Cha, S. (1996). Family and parenting behaviors predicting middle school adjustment: A longitudinal study. Family Relations, 45, 415-425.

Bryant, D., Vizzard, L. H., Willoughby, M., \& Kupersmidt, J. (1999). A review of interventions for preschoolers with aggressive and disruptive behavior. Early Education \& Development, 10, 45-68.

Burgoon, J. K. (1994). Nonverbal signals. In M. L. Knapp \& G. R. Miller (Eds.), Handbook of interpersonal communication (2nd ed., pp. 229-285). Thousand Oaks, CA: Sage.

Burleson, B. R., Delia, J. G., \& Applegate, J. L. (1992). Effects of maternal communication and children's social-cognitive and communication skills on children's acceptance by the peer group. Family Relations, 41, 264-272.

Burleson, B. R., Delia, J. G., \& Applegate, J. L. (1995). The socialization of person-centered communication: Parents' contributions to their children's social-cognitive and communication skills. In M. A. Fitzpatrick \& A. L. Vangelisti (Eds.), Explaining family interactions (pp. 34-76). Thousand Oaks, CA: Sage.

Burleson, B. R., \& Kunkel, A. W. (1996). The socialization of emotional support skills in childhood. In G. R. Pierce, B. S. Sarason, \& I. G. Sarason (Eds.), Handbook of social support and the family (pp. 105-140). New York: Plenum.

Bushman, B. J. (1995). Moderating role of trait aggressiveness in the effects of violent media on aggression. Journal of Personality and Social Psychology, 5, 950-960.

Campbell, S. B. (1995). Behavior problems in preschool children: A review of recent research. Journal of Child Psychology and Psychiatry, 36, 113-149.

Campbell, S. B. (1997). Behaviour problems in pre-school children. In T. H. Ollendick \& R. J. Printz (Eds.), Advances in child psychology (Vol. 19, pp. 1-26). New York: Plenum.

Carlson, E. A. (1998). A prospective longitudinal study of attachment disorganization/disorientation. Child Development, 4, 1107-1128.

Carson, L., \& Parke, R. (1996). Reciprocal negative affect in parent-child interactions and children's peer competency. Child Development, 67, 2217-2226.

Chamberlain, P., Patterson, G. R. (2002). Discipline and child compliance in parenting. In M. H. Bornstein (Series Ed.), Handbook of Parenting, Vol. 4 (pp. 203-226). New Jersey: Lawrence Erlbaum Associates.

Chen, X., Liu, M., \& Li, D. (2000). Parental warmth, control, and indulgence and their relations to adjustment in Chinese children: A longitudinal study. Journal of Family Psychology, 14, 401-419.

Chen, X., Wang, L., Chen, H., \& Liu, M. (2002). Noncompliance and child-rearing attitudes as predictors of aggressive behaviour: A longitudinal study in Chinese children. International Journal of Behavioral Development, 26, 255-233. 
Chung, T., \& Asher, S. R. (1996). Children's goals and strategies in peer conflict situations. Merrill-Palmer Quarterly, 42, 125-147.

Cicchetti, D., Lynch, M., Shonk, S., \& Manly, J. T. (1992). An organizational perspective on peer relations in maltreated children. In R. D. Parke \& G. W. Ladd (Eds.), Family-peer relationships: Modes of linkage (pp. 345-384). Hillsdale, NJ: Lawrence Erlbaum Associates.

Cline, F., \& Fay, J. (1992). Parenting teens with love and logic: Preparing adolescents for responsible adulthood. Colorado Springs, CO: Pinon Press.

Coie, J. D., \& Dodge, K. A. (1998). Aggression and antisocial behavior. In W. Damon (Series Ed.) \& N. Eisenberg (Vol. Ed.), Handbook of child psychology: Vol. 3. Social, emotional, and personality development (pp. 779-862). New York: Wiley.

Collins, W. A., Maccoby, E. E., Steinberg, L, Hetherington, E. M., \& Bornstein, M. H. (2000). Contemporary research on parenting: The case for nature and nurture. American Psychologist, 55, 218-232.

Conduct Problems Prevention Research Group. (1999). Initial impact of the fast track prevention trial for conduct problems: I. The high risk sample. Journal of Consulting and Clinical Psychology, 67, 631-647.

Contreras, J. M., Kerns, K. A., Weimer, B. L., Gentzler, A. L., \& Tomich, P. L. (2000). Emotion regulation as a mediator of associations between mother-child attachment and peer relationships in middle childhood. Journal of Family Psychology, 14, 111-124.

Coplan, R. J., Rubin, K. H., Fox, N. A., Calkins, S. D., \& Stewart, S. L. (1994). Being alone, playing alone, and acting alone: Distinguishing among reticence, and passive-and-active-solitude in young children. Child Development, 65, 129-137.

Cowan, P. A., Powell, D., \& Cowan, C. P. (1998). Parenting interventions: A family systems perspective. In W. Damon, I. Sigel, \& A. Renninger (Eds.), Handbook of child psychology (pp. 3-72). New York: Wiley.

Cowan, P. A., \& Cowan, C. P. (2002). What an intervention design reveals about how parents affect their children's academic achievement and behavior problems. In J. G. Borkowski, S. L. Ramey \& M. Bristol-Power (Eds.), Parenting and the child's world: Influences on academic, intellectual, and socio-emotional development (pp. 75-97). Mahwah, NJ: Lawrence Erlbaum Associates.

Crick, N. R., Casas, J. F., \& Ku, H. (1999). Relational and physical forms of peer victimization in preschool. Developmental Psychology, 35, 376-385.

Crick, N. R., \& Dodge, K. A. (1994). A review and reformulation of social information-processing mechanisms in children's social adjustment. Psychological Bulletin, 115, 74-101.

Crick, N. R., \& Werner, N. E. (1998). Response decision processes in relational and overt aggression. Child Development, 69, 1630-1639.

Crick, N. R., Werner, N. E., Casas, J. F., O’Brien, K. M., Nelson, D. A., Grotpeter, J. K., \& Markon, K. (1999). Childhood aggression and gender: A new look at an old problem. In D. Bernstein (Ed.), The Nebraska symposium on motivation (Vol. 45, pp. 75-141). Lincoln: University of Nebraska Press.

Crockenberg, S., Jackson, S., \& Langrock, A. M. (1996). Autonomy and goal attainment: Parenting, gender, and children's social competence. New Directions in Child Development, 73, 41-55.

Crockenberg, S., \& Lourie, A. (1996). Parents' conflict strategies with children and children's conflict strategies with peers. Merrill-Palmer Quarterly, 42, 495-518.

Darling, N., \& Steinberg, L. (1993). Parenting style as context: An integrative model. PsychologicalBulletin, 113, 487-496.

Deater-Deckard, K. (2000). Parenting and child behavioral adjustment in early childhood: A quantitative genetic approach to studying family processes. Child Development, 71, 468-484.

Deater-Deckard, K., \& Dodge, K. A. (1997). Externalizing behavior problems and discipline revisited: Nonlinear effects and variation by culture, context, and gender. Psychological Inquiry, 8, 161-175.

Deci, E. L., Eghrari, H., Patrick, B. C., \& Leone, D. R. (1994). Facilitating internalization: The selfdetermination theory perspective. Journal of Personality, 62, 119-142.

Deković, M., Gerris, J. R. M., \& Janssens, J. M. A. (1991). Parental cognitions, parental behavior, and the child's understanding of the parent-child relationship. Merrill-Palmer Quarterly, 37, 523541.

Deković, M., \& Janssens, J. M. A. (1992). Parents' child-rearing style and child's sociometric status. Developmental Psychology, 28, 925-932. 
Denham, S. A., Auerbach-Major, S. T., Kochanoff, A., \& Queenan, P. (2002). The unique and interactive contributions of child temperament and maternal induction to preschoolers' social competence. Manuscript submitted for publication.

Denham S., von Salisch, M., Olthof, T., Kochanoff, A., \& Caverly, S. (2002). Emotions and social development in childhood. In P. K. Smith \& C. H. Hart (Eds.), Blackwell handbook of childhood social development (pp. 307-328). Oxford, England: Blackwell.

Dishion, T. J., Duncan, T. E., Eddy, J. M., Fagot, B. I., \& Fetrow, R. (1994). The world of parents and peers: Coercive exchanges and children's social adaption. Social Development, 3, 255-268.

Dodge, K. A. (1985). Facets of social interaction and the assessment of social competence. In B. H. Schneider, K. H. Rubin, \& J. Ledingham (Eds.), Children's peer relations: Issues in assessment and intervention (pp. 3-22). New York: Springer-Verlag.

Dodge, K. A., Bates, J. E., \& Pettit, G. S. (1990). Mechanisms in the cycle of violence. Science, 250, 1678-1683.

Dodge, K. A., Pettit, G. S., Bates, J. E., \& Valente, E. (1995). Social information-processing patterns partially mediate the effect of early physical abuse on later conduct problems. Journal of Abnormal Psychology, 104, 632-643.

Dodge, K. A., \& Price, J. M. (1994). On the relation between social information processing and socially competent behavior in school aged children. Child Development, 65, 1385-1397.

Draper, T. W., Larsen, J. M., \& Rowles, R. (1997). Developmentally appropriate parent training for families with young children. Early Childhood Research Quarterly, 12, 487-504.

Duck, S. (1989). Socially competent communication and relationship development. In B. H. Schneider, G. Attili, J. Nadel, \& R. P. Weissberg (Eds.), Social competence in developmental perspective (pp. 91-106). Dordrecht, The Netherlands: Kluwer Academic.

Dumas, J. E. (1989). Treating antisocial behavior in children: Child and family approaches. Clinical Psychology Review, 9, 197-222.

Dumas, J. E., \& LaFreniere, P. J. (1995). Relationships as context: Supportive and coercive interactions in competent, aggressive, and anxious mother-child dyad. In J. McCord (Ed.), Coercion andpunishment in long-term perspectives (pp. 9-33). New York: Cambridge University Press.

Dumas, J. E., LaFreniere, P. J., \& Serketich, W. J. (1995). Balance of power: A transactional analysis of control in mother-child dyads involving socially competent, aggressive, and anxious children. Journal of Abnormal Psychology, 104, 104-113.

Dunn, J. (2002). Sibling relationships. In P. K. Smith \& C. H. Hart (Eds.), Blackwell handbook of childhood social development (pp. 223-237). Oxford, England: Blackwell.

Eaves, L. J., Eysenck, H. J., \& \& Martin, N. G. (1989). Genes, culture, and personality: An empirical approach. San Diego, CA: Academic Press.

Eddy, J. M., Dishion, T. J., \& Stoolmiller, M. (1998). The analysis of intervention change in children and families: Methodological and conceptual issues embedded in intervention studies. Journal of Abnormal Child Psychology, 26, 53-69.

Eisenberg, N., Fabes, R. A., Bernzweig, J., Karbon, M., Poulon, R., \& Hanish, L. (1993). The relations of emotionality and regulation to preschoolers' social skills and sociometric status. Child Development, 64, 1418-1438.

Eisenberg, N., Fabes, R. A., Guthrie, I. K., \& Reiser, N. (2000). Dispositional emotionality and regulation: Their role in predicting quality of social functioning. Journal of Personality and Social Psychology, 78, 136-157.

Eisenberg, N., Fabes, R. A., Murphy, B. C., Shepard, S., Guthrie, I. K., Mazsk, P., Poulin, R., \& Jones, S. (1999). Prediction of elementary school children's socially appropriate and problem behavior from anger reactions at age 4-6 years. Journal of Applied Developmental Psychology, 20, 119-142.

Eisenberg, N., \& Valiente, C. (2002). Parenting and children's prosocial and moral development. In M. H. Bornstein (Series Ed.), Handbook of Parenting, Vol. 5 (pp. 111-142). New Jersey: Lawrence Erlbaum Associates.

Eley, T. C., Lichtenstein, P., \& Stevenson, J. (1999). Sex differences in the etiology of aggressive and nonaggressive antisocial behavior: Results from two twin studies. Child Development, 70, 155-168.

Elicker, J., Egeland, B., \& Sroufe, L. A. (1992). Predicting peer competence and peer relationships in 
childhood from early parent-child relationships. In R. D. Parke \& G. W. Ladd (Eds.), Family-peer relationships: Modes of linkage (pp. 77-106). Hillsdale, NJ: Lawrence Erlbaum Associates.

Engfer, A. (1986). Antecedents of perceived behavior problems in infancy. In G. Kohnstamm (Eds.), Temperament discussed (pp. 165-180). Lisse, The Netherlands: Swets \& Zeitlinger.

Fabes, R. A., Leonard, S. A., Kupanoff, K., \& Martin C. L. (2001). Parental coping with children's negative emotions: Relations with children's emotional and social responding. Child Development, 27, 907-920.

Fagan, J., \& Iglesias, A. (2000). The relationship between fathers' and children's communication skills and children's behavior problems: A study of Head Start children. Early Education E Development, 11, 307-320.

Farber, S. L. (1981). Identical twins reared apart: A reanalysis. New York: Basic Books.

Farran, D. C. (1990). Effects of intervention with disadvantaged and disabled children: A decade review. In S. J. Meisels \& J. P. Shonkoff (Eds.), Handbook of early intervention (pp. 501-539). Cambridge, England: Cambridge University Press.

Farrington, D. P., Loeber, R., Elliott, D. S., Hawkins, J. D., Kandel, D. B., Klein, M. W., McCord, J., Rowe, D. C., \& Tremblay, R. E. (1990). Advancing knowledge about the onset of delinquency and crime. In B. B. Lahey \& A. E. Kazdin (Eds.), Advances in clinical child psychology (Vol. 13, pp. 283-342). New York: Plenum.

Feldman, R., Greenbaum, C. W., \& Yirmiya, N. (1999). Mother-infant affect and synchrony as an antecedent of the emergence of self-control. Developmental Psychology, 35, 223-231.

Finnie, V., \& Russell, A. (1988). Preschool children's social status and their mothers' behavior and knowledge in the supervisory role. Developmental Psychology, 24, 789-801.

Fish, M. (1997, April). Stability and change in infant temperament. Paper presented at the Society for Research in Child Development, Washington, DC.

Flannagen, D. (1996). Mothers' and kindergartners' talk about interpersonal relationships. Merrill-Palmer Quarterly, 42, 519-536.

Flannagan, D., \& Baker-Ward, L. (1996). Relations between mother-child discussions of children's preschool and kindergarten experiences. Journal of Applied Developmental Psychology, 17, 423-437.

Ford, M. (1982). Social cognition and social competence in adolescence. Developmental Psychology, 18, 323-340.

Forgatch, M. S., \& Patterson, G. R. (1989). Parents and adolescents living together: Part 2. Family problem solving. Eugene, OR: Castalia.

Fox, N. A., Henderson, H. A., Rubin, K. A., Calkins, S. D., \& Schmidt, L. A. (2001). Continuity and discontinuity of behavioral inhibition and exuberance: Psychophysiological and behavioral influences across the first four years of life. Child Development, 72, 1-21.

Fujiki, M., Brinton, B., Hart, C. H., \& Fitzgerald, A. H. (1999). Peer acceptance and friendship in children with specific language impairment. Topics in Language Disorders, 19, 34-48.

Fujiki, M., Brinton, B., Morgan, M., \& Hart, C. H. (1999). Withdrawal and sociable behavior of children with language impairment. Language, Speech, and Hearing Services in Schools, 30, 183-195.

Galen, B. R., \& Underwood, M. K. (1997). A developmental investigation of social aggression among children. Developmental Psychology, 33, 589-600.

Galper, A. (1998). Transitions in early childhood. In C. Seefeldt \& A. Galper (Eds.), Continuing issues in early childhood education (pp. 103-118). Upper Saddle River, NJ: Prentice-Hall.

Gershoff, E. T. (2002). Corporal punishment by parents and associated child behaviors and experiences: A meta-analytic and theoretical review. Psychological Bulletin, 128, 539-579.

Giles, H., \& Street, R. L., Jr. (1994). Communicator characteristics and behavior. In M. L. Knapp \& G. R. Miller (Eds.), Handbook of interpersonal communication (2nd ed., pp. 103-161). Thousand Oaks, CA: Sage.

Glasgow, K. L., Dornbusch, S. M., Troyer, L., Steinberg, L., \& Ritter, P. L. (1997). Parenting styles, adolescents' attributions, and educational outcomes in nine heterogeneous high schools. Child Development, 68, 507-529.

Gorman, J. C., \& Balter, L. (1997). Culturally sensitive parent education: A critical review of quantitative research. Review of Educational Research, 67, 339-369.

Gottman, J., \& DeClaire, J. (1997). The heart of parenting: How to raise an emotionally intelligent child. New York: Simon \& Schuster. 
Gray, M. R., \& Steinberg, L. (1999). Unpacking authoritative parenting: Reassessing a multidimensional construct. Journal of Marriage and the Family, 61, 574-587.

Gresham, F. M. (1986). Conceptual issues in the assessment of social competence in children. In P. S. Strain, M. J. Guralnick, \& H. M. Walker (Eds.), Children's social behavior: Development, assessment, and modification (pp. 143-180). Orlando, FL: Academic Press.

Gresham, F. M., \& Elliott, S. N. (1990). Social skills rating system. Circle Pines, MN: American Guidance Service.

Grolnick, W. S. (2003). The psychology of parental control. Mahwah, NJ: Lawrence Erlbaum Associates.

Grotpeter, J. K. (1997). Relational aggression, overt aggression, and family relationships. Unpublished doctoral dissertation, University of Illinois at Urbana-Champaign.

Grusec, J. E. (2002). Parental socialization and children's acquisition of values. In. M. H. Bornstein (Series Ed.), Handbook of Parenting, Vol. 5 (pp. 143-168). New Jersey: Lawrence Erlbaum Associates.

Grusec, J. E., Davidov, M., \& Lundell, L. (2002). Prosocial and helping behavior. In P. K. Smith \& C. H. Hart (Eds.), Blackwell handbook of childhood social development (pp. 457-474). Oxford, England: Blackwell.

Grusec, J. E., \& Goodnow, J. J. (1994). Impact of parental discipline methods on the child's internalization of values: A reconceptualization. Developmental Psychology, 30, 4-19.

Guralnick, M. J., Conner, R. T., Hammond, M. A., Gottman, J. M., \& Kinnish, K. (1996). The peer relations of preschool children with communication disorders. Child Development, 67, 471-489.

Harris, J. R. (1995). Where is the child's environment? A group socialization theory of development. Psychological Review, 102, 458-489.

Harris, J. R. (1998). The nurture assumption: Why children turn out the way they do. New York: Free Press.

Harris, J. R. (2000). Socialization, personality development, and the child's environments: Comment on Vandell (2000). Developmental Psychology, 36, 711-723.

Harris, J. R. (2002). Beyond the nurture assumption: Testing hypotheses about the child's environment. In J. G. Borkowski, S. L. Ramey, \& M. Bristol-Power (Eds.), Parenting and the child's world: Influences on acadamic, intellectual, and social-emotional development. Mahwah, NJ: Lawrence Erlbaum Associates.

Harrist, A. W., Pettit, G. S., Dodge, K. A., \& Bates, J. E. (1994). Dyadic synchrony in mother-child interaction: Relation with children's subsequent kindergarten adjustment. Family Relations, 43, 417424.

Hart, C. H. (1999, November). Combating the myth that parents don't matter. Paper presented at the World Congress of Families II, Geneva, Switzerland.

Hart, C. H., DeWolf, M. D., \& Burts, D. C. (1992). Linkages among preschoolers' playground behavior, outcome expectations, and parental disciplinary strategies. Early Education and Development, 3, 265283.

Hart, C. H., DeWolf, M. D., \& Burts, D. C. (1993). Parental disciplinary strategies and preschoolers' play behavior in playground settings. In C. H. Hart (Ed.), Children on playgrounds: Research perspectives and applications (pp. 271-313). Albany, NY: SUNY Press.

Hart, C. H., DeWolf, M. D., Wozniak, P., \& Burts, D. C. (1992). Maternal and paternal disciplinary styles: Relations with preschoolers' playground behavioral orientations and peer status. Child Development, 63, 879-892.

Hart, C. H., Ladd, G. W., \& Burleson, B. R. (1990). Children's expectations of the outcomes of social strategies: Relations with sociometric status and maternal disciplinary styles. Child Development, 61, $127-137$.

Hart, C. H., McGee, L., \& Hernandez, S. (1993). Themes in the peer relations literature: Correspondence to playground interactions portrayed in children's literature. In C. H. Hart (Ed.), Children onplaygrounds: Research perspectives and applications (pp. 371-416). Albany, NY: SUNY Press.

Hart, C. H., Nelson, D. A., Robinson, C. C., Olsen, S. F., \& McNeilly-Choque, M. K. (1998). Overt and relational aggression in Russian nursery-school-age children: Parenting style and marital linkages. Developmental Psychology, 34, 687-697.

Hart, C. H., Nelson, D. A., Robinson, C. C., Olsen, S. F., McNeilly-Choque, M. K., Porter, C. L., \& McKee, T. R. (2000). Russian parenting styles and family processes: Linkages with subtypes of victimization 
and aggression. In K. A. Kerns, J. M. Contreras, \& A. M. Neal-Barnett (Eds.), Family and peers: Linking two social worlds (pp. 47-84). Westport, CT: Praeger.

Hart, C. H., Newell, L. D., \& Sine, L. (2000). Proclamation-based principles of parenting and supportive scholarship. In D. C. Dollahite (Ed.), Strengthening ourfamilies: An in-depth look at the proclamation on the family (pp. 100-123). Salt Lake City, UT: Bookcraft.

Hart, C. H., Olsen, S. F., Robinson, C., \& Mandleco, B. L. (1997). The development of social and communicative competence in childhood: Review and a model of personal, familial, and extrafamilial processes. In B. R. Burleson (Ed.), Communication yearbook 20 (pp. 305-373). Thousand Oaks, CA: Sage.

Hart, C. H., Yang, C., Nelson, D., Jin, S., \& Nelson, L. (1998). Peer contact patterns, parenting practices, and preschoolers' social competence in China, Russia, and the United States. In P. Slee \& K. Rigby (Eds.), Peer relations amongst children: Current issues and future directions (pp. 1-30). London: Routledge.

Hart, C. H., Yang, C., Nelson, L. J., Robinson, C. C., Olsen, J. A., Nelson, D. A., Porter, C. L., Jin, S., Olsen, S. F., \& Wu, P. (2000). Peer acceptance in early childhood and subtypes of withdrawn behavior in China, Russia, and the United States. International Journal of Behavioral Development, 24, 73-81.

Hartup, W. W., \& Abecassis, M. (2002). Friends and enemies. In P. K. Smith \& C. H. Hart (Eds.), Blackwell handbook of childhood social development (pp. 285-306). Oxford, England: Blackwell.

Hastings, P. D., \& Rubin, K. H. (1999). Predicting mothers' beliefs about preschool-aged children's social behavior: Evidence for maternal attitudes moderating child effects. Child Development, 70, 722-741.

Heller, T. L., \& Baker, B. L. (2000). Maternal negativity and children's externalizing behavior. Early Education \& Development, 11, 483-498.

Hill, J., \& Maughan, B. (2002). Conduct disorders in childbood and adolescence. Cambridge, England: Cambridge University Press.

Hinshaw, S. P. (1997). Contextual effects, configural analysis, and nonlinearity pertain to externalizing behavior as well as to parental discipline. Psychological Inquiry, 8 (3), 161-175.

Hinshaw, S. P., Zupan, B. A., Simmel, C., Nigg, J. T., \& Melnick, S. (1997). Peer status in boys with and without attention-deficit hyperactivity disorder: Predictions from overt and covert antisocial behavior, social isolation, and authoritative parenting beliefs. Child Development, 68, 880-896.

Hoffman, L. W. (1991). The influence of the family environment on personality: Accounting for sibling differences. Psychological Bulletin, 108, 187-203.

Hoffman, L. W. (1994a). Commentary on Plomin, R. (1994). A proof and a disproof questioned. Social Development, 3, 60-63.

Hoffman, M. L. (1983). Affective and cognitive processes in moral internalization. In E. T. Higgins, D. Ruble, \& W. W. Hartup (Eds.), Social cognition and social development: A sociocultural perspective (pp. 236-274). New York: Cambridge University Press.

Hoffman, M. L. (1994b). Discipline and internalization. Developmental Psychology, 30, 26-28.

Holden, G. W., Coleman, S. M., \& Schmidt, K. L. (1995). Why 3-year-old children get spanked: Parent and child determinants as reported by college-age mothers. Merrill-Palmer Quarterly, 41, 431-449.

Holden, G. W., \& Miller, P. C. (1999). Enduring and different: A meta-analysis of the similarity in parents' child rearing. Psychological Bulletin, 125, 223-254.

Howes, C., \& James, J. (2002). Children's social development within the socialization context of child care and early childhood. In P. K. Smith \& C. H. Hart (Eds.), Blackwell handbook of childhood social development (pp. 137-155). Oxford, England: Blackwell.

Howrigan, G. A. (1988). Evaluating parent-child interaction outcomes of family support and education programs. In H. B. Weiss \& F. H. Jacobs (Eds.), Evaluating family programs: Modern applications of social work (pp. 95-130). Hawthorne, NY: Aldine de Gruyter.

Ialongo, N., Edelsohn, G., Werthamer-Larsson, L., Crockett, L., \& Kellam, S. (1996). Social and cognitive impairment in first-grade children with anxious and depressive symptoms. Journal of Clinical Child Psychology, 25, 15-24.

Isley, S. L., O'Neil, R., Clatfelter, D., \& Parke, R. D. (1999). Parent and child expressed affect and children's social competence: Modeling direct and indirect pathways. Developmental Psychology, 35, 547-560.

Isley, S., O'Neil, R., \& Parke, R. D. (1996). The relation of parental affect and control behaviors to children's classroom acceptance: A concurrent and predictive analysis. Early Education and Development, 7, $7-23$. 
Iverson, J. M., \& Goldin-Meadow, S. (1998). The nature and functions of gesture in children's communication. In W. Damon (Series Ed.), New directions for child development (Number 79). San Francisco: Jossey-Bass.

Johnson, D. L., \& Walker, T. (1987). Primary prevention of behavior problems in Mexican-American children. American Journal of Community Psychology, 15, 375-385.

Kahen, V., Katz, L. F., \& Gottman, J. M. (1994). Linkages between parent-child interactions and conversations of friends. Social Development, 3, 238-254.

Kandel, D. B., \& Wu, P. (1995). Disentangling mother-child effects in the development of antisocial behavior. In J. McCord (Ed.), Coercion and punishment in long-term perspectives (pp. 106-123). New York: Cambridge University Press.

Kazdin, A. E. (1990). Prevention of conduct disorder. Rockville, MD: National Institute of Mental Health.

Kemple, K., Speranza, H., \& Hazen, N. (1992). Cohesive discourse and peer acceptance: Longitudinal relations in the preschool years. Merrill-Palmer Quarterly, 38, 364-381.

Kerr, M., \& Stattin, H. (2000). What parents know, how they know it, and several forms of adolescent adjustment: Further support for a reinterpretation of monitoring. Developmental Psychology, 36, 366380 .

Kochanska, G. (1992). Children's interpersonal influence with mothers and peers. Developmental Psychology, 28, 491-499.

Kochanska, G. (1993). Toward a synthesis of parental socialization and child temperament in early development of conscience. Child Development, 64, 325-347.

Kochanska, G. (1995). Children's temperament, mothers' discipline, and security of attachment: Multiple pathways to emerging internalization. Child Development, 66, 597-615.

Kochanska, G. (1997a). Multiple pathways to conscience for children with different temperaments: From toddlerhood to age 5. Developmental Psychology, 33, 228-240.

Kochanska, G. (1997b). Mutually responsive orientation between mothers and their children: Implications for early socialization. Child Development, 68, 94-112.

Kochanska, G., Aksan, N., \& Koenig, A. L. (1995). A longitudinal study of the roots of preschoolers' conscience: Committed compliance and emerging internalization. Child Development, 66, 1752-1769.

Kochanska, G., Coy, K. C., Murray, K. T. (2001). The development of self-regulation in the first four years of life. Child Development, 72, 1091-1111.

Kochanska, G., \& Murray, K. T. (2000). Mother-child mutually responsive orientation and conscience development: From toddler to early school age. Child Development, 71, 417-431.

Kowal, A., \& Kramer, L. (1997). Children's understanding of parental differential treatment. Child Development, 68, 113-126.

Krappman, L. (1989). Family relationships and peer relationships in middle childhood. In K. Kreppner \& R. M. Lerner (Eds.), Family systems and life span development (pp. 93-104). Hillsdale, NJ: Lawrence Erlbaum Associates.

Krevans, J., \& Gibbs, J. C. (1996). Parents' use of inductive discipline: Relations to childrens' empathy and prosocial behavior. Child Development, 67, 3263-3277.

Kuczynski, L. (1984). Socialization goals in mother-child interaction: Strategies for long-term and shortterm compliance. Developmental Psychology, 20, 1061-1073.

Kuczynski, L., \& Kochanska, G. (1995). Function and content of maternal demands: Developmental significance of early demands for competent action. Child Development, 66, 616-628.

Kuczynski, L., \& Lollis, S. (In press). Four foundations for a dynamic model of parenting. In J. R. M. Gerris (Ed.), Dynamics of parenting. Hillsdale, NJ: Lawrence Erlbaum Associates.

Ladd, G. W., Buhs, E. S., \& Troop, W. (2002). Children's interpersonal skills and relationships in school settings: Adaptive significance and implications for school-based prevention and intervention programs. In P. K. Smith \& C. H. (Eds.), Blackwell handbook of childhood social development (pp. 394-416). Oxford, England: Blackwell.

Ladd, G. W., \& Burgess, K. B. (1999). Charting the relationship trajectories of aggressive, withdrawn, and aggressive/withdrawn children during early grade school. Child Development, 70, 910-929.

Ladd, G. W., \& Golter, B. S. (1988). Parents' management of preschooler's peer relations: Is it related to children's social competence? Developmental Psychology, 24, 109-117.

Ladd, G. W., \& Hart, C. H. (1992). Creating informal play opportunities: Are parents' and preschoolers' initiations related to children's competence with peers? Developmental Psychology, 28, 1179-1187. 
Ladd, G. W., Hart, C. H., Wadsworth, E. M., \& Golter, B. S. (1988). Preschoolers' peer networks in nonschool settings: Relationship to family characteristics and school adjustment. In S. Salzinger, J. Antrobus, \& M. Hammer (Eds.), Social networks of children, adolescents, and college students (pp. 61-92). Hillsdale, NJ: Lawrence Erlbaum Associates.

Ladd, G. W., \& Le Sieur, K. D. (1995). Parents' and children's peer relationships. In M. H. Bornstein (Ed.), Handbook of parenting (Vol. 4, pp. 377-409). Mahwah, NJ: Lawrence Erlbaum Associates.

Ladd, G. W., \& Pettit, G. S. (2002). Parenting and the development of children's peer relationships. In M. H. Bornstein (Series Ed.), Handbook of Parenting, Vol. 5 (pp. 269-310). New Jersey: Lawrence Erlbaum Associates.

Ladd, G. W., Profilet, S. M., \& Hart, C. H. (1992). Parents' management of children's peer relations: Fostering and supervising children's activities in the peer culture. In R. D. Parke \& G. W. Ladd (Eds.), Family-peer relationships: Modes of linkage (pp. 215-253). Hillsdale, NJ: Lawrence Erlbaum Associates.

Laird, R. D., Pettit, G. S., Mize, J., Brown, E. G., \& Lindsey, E. (1994). Mother-child conversations about peers: Contributions to competence. Family Relations, 43, 425-432.

Lamb, M. E., Hwang, C. P., Ketterlinus, R. D., \& Fracasso, M. P. (1999). Parent-child relationships: Development in the context of the family. In M. H. Bornstein \& M. E. Lamb (Eds.), Developmentalpsychology: An advanced textbook (pp. 411-450, 4th Edition). Mahwah, NJ: Lawrence Erlbaum Associates.

Lamb, M. E., Ketterlinus, R. D., \& Fracasso, M. P. (1992). Parent-child relationships. In M. H. Bornstein \& M. E. Lamb (Ed.), Developmental psychology: An advanced textbook (pp. 465-518, 2nd Edition). Hillsdale, NJ: Lawrence Erlbaum Associates.

Lamborn, S. D., Dornbusch, S. M., \& Steinberg, L. (1996). Ethnicity and community context as moderators of the relations between family decision making and adolescent adjustment. Child Development, 67, 283-301.

Larzelere, R. E. (1996). A review of the outcomes of parental use of nonabusive or customary physical punishment. Pediatrics, 98, 824-828.

Lazelere, R. E., Sather, P. R., Schneider, W. N., Larson, D. B., \& Pike, P. L. (1998). Punishment enhances reasoning's effectiveness as a disciplinary response to toddlers. Journal of Marriage and the Family, $60,388-403$.

Lepper, M. R. (1981). Intrinsic and extrinsic motivation in children: Detrimental effects of superfluous social controls. In W. A. Collins (Ed.), Minnesota symposium on child psychology (pp. 155-214). Minneapolis: University of Minnesota Press.

Leve, L. D., Winebarger, A. A., Fagot, B. I., Reid, J. B., \& Goldsmith, H. H. (1998). Environmental and genetic variance in children's observed and reported maladaptive behavior. Child Development, 69, 1286-1298.

Lindsey, E. W., \& Mize, J. (2000). Parent-child physical and pretense play: Links to children's social competence. Merrill-Palmer Quarterly, 46, 565-591.

Loeber, R., \& Dishion, T. (1983). Early predictors of male delinquency: A review. Psychological Bulletin, 94, 68-99.

Loehlin, J. C. (2001). Behavior genetics and parenting theory. American Psychologist, 56, 169-170.

Lytton, H. (1990). Child and parent effects in boys' conduct disorder: A reinterpretation. Developmental Psychology, 26, 683-697.

Lytton, H., \& Romney, D. (1991). Parental differential socialization of boys and girls. Psychological Bulletin, 109, 267-296.

MacKinnon-Lewis, C., Rabiner, D., \& Starnes, R. (1999). Predicting boys' social acceptance and aggression: The role of mother-child interactions and boys' beliefs about peers. Developmental Psychology, 35, 632-639.

MacKinnon-Lewis, C., Starnes, R., Volling, B., \& Johnson, S. (1997). Perceptions of parenting as predictors of boys' sibling and peer relations. Child Development, 33, 1024-1031.

MacKinnon-Lewis, C., Volling, B. L., Lamb, M. E., Dechman, K., Rabiner, D., \& Curtner, M. E. (1994). A cross-contextual analysis of boys' social competence: From family to school. Developmental Psychology, 30, 325-333.

Maccoby, E. E. (1983). Let's not overattribute to the attribution process: Comments on social cognition and behavior. In E. T. Higgins, D. N. Ruble, \& W. W. Hartup (Eds.), Social cognition and social development: A sociocultural perspective (pp. 356-370). Cambridge, England: Cambridge University Press. 
Maccoby, E. E., \& Martin, J. A. (1983). Socialization in the context of the family: Parent-child interaction. In P. H. Mussen (Series Ed.) \& E. M. Hetherington (Vol. Ed.), Handbook of child psychology: Vol. 4. Socialization, personality and social development (pp. 1-102). New York: Wiley.

Mash, E. J., \& Barkley, R. A. (1998). Treatment of childhood disorders. New York: Guilford Press.

Mattanah, J. F. (2001). Parental psychological autonomy and children's academic competence and behavioural adjustment in late childhood: More than just limit-setting and warmth. Merrill-Palmer Quarterly, 47, 355-376.

McDougall, P., Hymel, S., Vaillancourt, T., \& Mercer, L. (2001). The consequences of childhood peer rejection. In M. Leary (Ed.), Interpersonal rejection (pp. 213-247). London: Oxford University Press.

McFadyen-Ketchum, S. A., Bates, J. E., Dodge, K. A., \& Pettit, G. S. (1996). Patterns of change in early childhood aggressive-disruptive behavior: Gender difference in predictions from early coercive and affectionate mother-child interactions. Child Development, 67, 2417-2433.

McFadyen-Ketchum, S. A., \& Dodge, K. A. (1998). Problems in social relationships. In E. J. Mash \& R. A. Barkley (Eds.), Treatment of childhood disorders (pp. 338-365). New York: Guilford Press.

McFall, R. M. (1982). A review and reformulation of the concept of social skills. Behavioral Assessment, 4, 1-33.

McGrath, M. P., Wilson, S. R., \& Frassetto, S. J. (1995). Why some forms of induction are better than others at encouraging prosocial behavior. Merrill-Palmer Quarterly, 41, 347-360.

McGue, M., Sharma, A., \& Benson, P. (1996). The effect of common rearing on adolescent development: Evidence from a U. S. adoption court. Developmental Psychology, 32, 604-613.

McGuire, S., Dunn, J., \& Plomin, R. (1995). Maternal differential treatment of siblings and children's behavioral problems: A longitudinal study. Development and Psychopathology, 7, 515-528.

McMahon, R. J., \& Wells, K. C. (1989). Conduct disorder. In E. J. Mash \& R. A. Barkley (Eds.), Treatment of childhood disorders (pp. 73-134). New York: Guilford Press.

McNeil, C. B., Capage, L. C., Bahl, A., \& Blanc, H. (1999). Importance of early intervention for disruptive behavior problems: Comparison of treatment and waitlist-control groups. Early Education and Development, 10, 445-454.

Mills, R. S. L., \& Rubin, K. H. (1993). Parental ideas as influences on children's social competence. In S. Duck (Ed.), Learning about relationships (pp. 98-117). Newbury Park, CA: Sage.

Mize, J., \& Pettit, G. S. (1997). Mothers' social coaching, mother-child relationship style and children's peer competence: Is the medium the message? Child Development, 68, 291-311.

Mize, J., Pettit, G. S., \& Brown, G. (1995). Mothers' supervision of their children's peer play: Relations with beliefs, perceptions, and knowledge. Developmental Psychology, 31, 311-321.

Mize, J., Russell, A., \& Pettit, G. S. (1998). Further explorations of family-peer connections: The role of parenting practices and parenting style in children's development of social competence. In P. T. Slee \& K. Rigby (Eds.), Children's peer relations (pp. 31-44). New York: Routledge.

Morris, A. S., Silk, J. S., Steinberg, L., Sessa, F., Avenevoli, S., \& Essex, M. J. (2002). Temperamental vulnerability and negative parenting as interacting predictors of child adjustment. Journal of marriage and Family, 64, 461-471.

Murphy, B. C., \& Eisenberg, N. (1996). Provoked by a peer: Children's anger-related responses and their relations to social functioning. Merrill-Palmer Quarterly, 42, 103-124.

Nelson, D. A., \& Crick, N. R. (2002). Parental psychological control: Implications for childhood physical and relational aggression (pp. 161-189). In B. Barber (Ed.), Psychological control of children and adolescents. Washington, DC: American Psychological Association.

Nix, R. L., Pinderhughes, E. E., Dodge, K. A., Bates, J. E., Pettit, G. S., \& McFadyen-Ketchum, S. A. (1999). The relation between mothers' hostile attribution tendencies and children's externalizing behavior problems: The mediating role of mothers' harsh discipline practices. Child Development, 70, 896-909.

Nucci, L., \& Smetana, J. G. (1996). Mothers' concepts of young childrens' areas of personal freedom. Child Development, 67, 1870-1886.

Nucci, L. P., \& Weber, E. K. (1995). Social interactions in the home and the development of young children's conceptions of the personal. Child Development, 66, 1438-1452.

O'Connor, T. G., Deater-Deckard, K., Fulker, D., Rutter, M., \& Plomin, R. (1998). Genotype-environment correlations in late childhood and early adolescence: Antisocial behavioral problems and coercive parenting. Developmental Psychology, 34, 970-981. 
Odom, S. L., \& McConnell, S. R. (1992). Improving social competence: An applied behavior analysis perspective. Journal of Applied Behavior Analysis, 25, 239-244.

Olsen, S. F., Yang, C., Hart, C. H., Robinson, C. C., Wu, P., Nelson, D. A., Nelson, L. J., Jin, S., \& Wo, J. (2002). Maternal psychological control and preschool children's behavioral outcomes in China, Russia, and the United States. In B. Barber (Ed.), Intrusiveparenting: How psychological control affects children and adolescents. Washington, DC: American Psychological Association.

Olson, S. L., Bates, J. E., Sandy, J. M., \& Lanthier, R. (2000). Early development precursors of externalizing behavior in middle childhood and adolescence. Journal of Abnormal Child Psychology, 28, 119-133.

Olweus, D. (1994). Bullying at school: Basic facts and effects of a school based intervention program. Journal of Child Psychology and Psychiatry, 35, 1171-1190.

Parke, R. D., Burks, V. M., Carson, J. L., Neville, B., \& Boyum, L. A. (1994). Family-peer relationships: A tripartite model. In R. D. Parke \& S. G. Kellam (Eds.), Exploring family relationships within other social contexts (pp. 115-145). Hillsdale, NJ: Lawrence Erlbaum Associates.

Parke, R. D., Simpkins, S. D., McDowell, D. J., Kim, M., Killian, C., Dennis, J., Flyr, M. L., Wild, M., \& Rah, Y. (2002). Relative contributions of families and peers to children's social development (pp. 235-262). In P. K. Smith \& C. H. Hart (Eds.), Blackwell handbook of childhood social development (pp. 156-178). Oxford, England: Blackwell.

Patterson, G. R., (1982). Coercive family process. Eugene, OR: Castalia.

Patterson, G. R., Dishion, T. J., \& Chamberlain, P. (1993). Outcomes and methodological issues relating to treatment of antisocial children. In T. R. Giles (Ed.), Handbook of effective psychotherapy (pp. 43-88). New York: Plenum.

Patterson, G. R., \& Fisher, P. A. (2002). Recent developments in our understanding of parenting: Bidirectional effects, casual models, and the search for parsimony. In M. H. Bornstein (Series Ed.), Handbook of Parenting: Vol. 5 (pp. 59-88). New Jersey: Lawrence Erlbaum Associates.

Patterson, G. R., Reid, J. B., \& Dishion, T. J. (1992). Antisocial boys. Eugene, OR: Castalia.

Paterson, G., \& Sanson, A. (1999). The association of behavioural adjustment to temperament, parenting, and family characteristics among 5-year-old children. Social Development, 8, 293-309.

Pettit, G. S., \& Bates, J. E. (1989). Family interaction patterns and children's behavior problems from infancy to 4 years. Developmental Psychology, 25, 413-420.

Pettit, G. S., Bates, J. E., \& Dodge, K. A. (1997). Supportive parenting, ecological context, and children's adjustment: A seven-year study. Child Development, 68, 908-923.

Pettit, G. S., Brown, E. G., Mize, J., \& Lindsey, E. (1998). Mothers' and fathers' socializing behaviors in three contexts: Links with children's peer competence. Merrill-Palmer Quarterly, 44, 173-193.

Pettit, G. S., Clawson, M. A., Dodge, K. A., \& Bates, J. E. (1996). Stability and change in peer-rejected status: The role of child behavior, parenting, and family ecology. Merrill-Palmer Quarterly, 42, 267294.

Pettit, G. S., Laird, R. D., Dodge, K. A., Bates, J. E., \& Criss, M. M. (2001). Antecedents and behaviorproblem outcomes of parental monitoring and psychological control in early adolescents. Child Development, 72, 583-598.

Pettit, G. S., \& Lollis, S. (1997). Reciprocity and bidirectionality in parent-child relationships. Journal of Social and Personal Relationships, 14, 435-440.

Pettit, G. S., Polaha, J. A., \& Mize, J. (2001). Perceptual and attributional processes in aggression and conduct problems. In J. P. Hill \& B. Maughan (Eds.), Conduct disorders in childhood. Cambridge, England: Cambridge University Press.

Pike, A. (2002). Behavioral genetics: Shared and non-shared environment. In P. K. Smith \& C. H. Hart (Eds.), Blackwell handbook of childhood social development (pp. 27-43). Oxford, England: Blackwell.

Pike, A., McGuire, S., Hetherington, E. M., Reiss, D., \& Plomin, R. (1996). Family environment and adolescent depressive symptoms and antisocial behavior: A multivariate genetic analysis. Developmental Psychology, 32, 590-603.

Plomin, R. (1990). Nature and nurture. Pacific Grove, CA: Brooks/Cole.

Plomin, R. (1994). Nature, nurture, \& social development. Social Development, 3, 37-53.

Plomin, R. (2000). Behavioral genetics in the 21st century. International Journal of Behavioral Development, 24, 30-34. 
Plomin, R., Corley, R., DeFries, J. C., \& Fulker, D. W. (1990). Individual differences in televison viewing in early childhood: Nature as well as nurture. Psychological Science, 1, 371-377.

Plomin, R., DeFries, J., McClearn, G., \& Rutter, M. (1997). Behavioral genetics (3rd ed.). New York: Freeman.

Plomin, R., Reiss, D., Hetherington, E. M., \& Howe, G. W. (1994). Nature and nurture: Genetic contributions to measures of the family environment. Developmental Psychology, 30, 32-43.

Plomin, R., \& Rutter, M. (1998). Child development, molecular genetics, and what to do with genes once they are found. Child Development, 69, 1223-1242.

Powell, D. R. (1998). Reweaving parents into the fabric of early childhood programs. Young Children, 53, 60-67.

Powell, D. R. (1994). Evaluating family support programs: Are we making progress? In S. L. Kagan \& B. Weissbound (Eds.), Putting families first: America's family support movement and the challenge of change (pp. 441-470). San Francisco: Jossey-Bass.

Prinstein, M. J. (1997). Maternalsocial competence, mothers'socialmanagement behavior, and children's social competence: A mediational model. Unpublished doctoral dissertation, University of Miami, Coral Gables, FL.

Profilet, S. M., \& Ladd, G. W. (1994). Do mothers' perceptions and concerns about preschoolers' peer competence predict their peer-management practices? Social Development, 3, 205-221.

Profilet, S. M., \& Ladd G. W. (1996, April). Relations between maternal consulting about kindergarten children's peer relationships and children's peer competence. Paper presented at the annual meeting of the American Educational Research Association, New York.

Putallaz, M. (1987). Maternal behavior and sociometric status. Child Development, 58, 324-340.

Putallaz, M., \& Heflin, A. H. (1990). Parent-child interaction. In S. R. Asher \& J. D. Coie (Eds.), Peer rejection in childhood: Origins, consequences, and intervention (pp. 274-305). Cambridge, England: Cambridge University Press.

Resnick, M. D., Bearman, P. S., Blum, R. N., Bauman, K. E., Harris, K. M., Jones, J., Taber, J., Benhring, T., Sieving, R. E., Shew, M., Ireland, M., Bearinger, L. H., \& Udry, J. R. (1997). Protecting adolescents from harm: Findings from the national longitudinal study on adolescent health. Journal of the American Medical Association, 278, 823-832.

Reynolds, A. J. (1994). Effects of preschool plus follow-on intervention for children at risk. Developmental Psychology, 30, 787-804.

Robinson, J. L., Kagan, J., Reznick, J. S., \& Corley, R. (1992). The heritability of inhibited and uninhibited behavior: A twin study. Developmental Psychology, 28, 1030-1037.

Rodgers, D. B. (1998). Supporting autonomy in young children. Young Children, 75-80.

Rodkin, P. C., Farmer, T. W., Pearl, R., \& Van Acker, R. (2000). Heterogeneity of popular boys: Antisocial and prosocial configurations. Developmental Psychology, 36, 14-24.

Rose-Krasnor, L. (1997). The nature of social competence: A theoretical review. Social Development, 6, 111-135.

Rothbart, M. K., \& Bates, J. E. (1998). Temperament. In N. Eisenberg (Ed.), Handbook of childpsychology: Vol. 3: Social, emotional, and personality development (pp. 105-176). New York: Wiley.

Rowe, D. C. (1994). The limits offamily influence: Genes, experience, and behavior. New York: Guilford Press.

Rowe, D. C. (2001). The nurture assumption persists. American Psychologist, 56, 168-169.

Rowe, D. C. (2002). What twin and adoption studies reveal about parenting. In J. G. Borkowski, S. L. Ramey, \& M. Bristol-Power(Eds.), Parenting and the child's world: Influence on academic, intellectual, and social-emotional development. Mahwah, NJ: Lawrence Erlbaum Associates.

Rubin, K. H., Bukowski, W., \& Parker, J. G. (1998). Peer interactions, relationships, and groups. In N. Eisenberg (Ed.), Handbook of child psychology: Vol. 3. Social, emotional, and personality development (pp. 619-700). New York: Wiley.

Rubin, K. H., Burgess, K., \& Coplan, R. (2002). Social withdrawal and shyness. In P. K. Smith \& C. H. Hart (Eds.), Blackwell handbook of childhood social development (pp. 329-352). Oxford, England: Blackwell.

Rubin, K. H., Burgess, K. B., \& Hastings, P. D. (2002). Stability and social-behavioral consequences of toddlers' inhibited temperament and parenting behaviors. Child Development, 73, 483-495. 
Rubin, K. H., Cheah, C. S., \& Fox, N. (2001). Emotional regulation parenting and display of social reticence in preschoolers. Early Education E Development, 12, 97-115.

Rubin, K. H., \& Clarke, M. L. (1983). Preschool teachers' rating of behavioral problems: Observational, sociometric, and social-cognitive correlates. Journal of Abnormal Child Psychology, 11, 273286.

Rubin, K. H., Coplan, R. J., Fox, N. A., \& Calkins, S. D. (1995). Emotionality, emotion regulation, and preschoolers' social adaptation. Development and Psychopathology, 7, 49-62.

Rubin, K. H., Coplan, R. J., Nelson, L. J., \& Lagace-Seguin, D. G. (1999). Peer relationships in childhood. In M. H. Bornstein \& M. E. Lamb (Eds.), Developmental psychology: An advanced textbook (pp. 451-501). Mahwah, NJ: Lawrence Erlbaum Associates.

Rubin, K. H., Nelson, L. J., Hastings, P., \& Asendorpf, J. (1999). The transaction between parents' perceptions of their children's shyness and their parenting styles. International Journal of Behavioral Development, 23, 937-957.

Rubin, K. H., \& Rose-Krasnor, L. (1992). Interpersonal problem solving and social competence in children. In V. B. Van Hasselt \& M. Hersen (Ed.), Handbook of social development: A lifespan perspective (pp. 283-323). New York: Plenum.

Rubin, K. H., Stewart, S. L., \& Chen, X. (1995). Parents of aggressive and withdrawn children. In M. H. Bornstein (Ed.), Handbook of parenting: Vol. 1. Children and parenting (pp. 255-284). Mahwah, NJ: Lawrence Erlbaum Associates.

Russell, A., \& Finnie, V. (1990). Preschool children's social status and maternal instructions to assist group entry. Developmental Psychology, 26, 603-611.

Russell, A., Hart, C. H., Robinson, C. C., \& Olsen, S. F. (in press). Children's sociable and aggressive behavior with peers: A comparison of the U.S. and Australia, and contributions of temperament and parenting styles. International Journal of Behavioural Development.

Russell, A., Mize, J., \& Bissaker, K. (2002). Parent-child relationships. In P. K. Smith \& C. H. Hart (Eds.), Blackwell handbook of childhood social development (pp. 205-222). Oxford, England: Blackwell.

Russell, A., \& Russell, G. (1994). Coparenting early school-age children: An examination of mother-father interdependence within families. Developmental Psychology, 30, 757-770.

Russell, A., \& Russell, G. (1996). Positive parenting and boys' and girls' misbehavior during a home observation. International Journal of Behavioral Development, 19, 291-307.

Sanders, M. R., Montgomery, D. T., \& Brechman-Toussaint, M. L. (2000). The mass media and the prevention of child behavior problems: The evaluation of a television series to promote positive outcomes for parents and their children. Journal of Child Psychology and Psychiatry, 41, 939-948.

Sanson, A., Hemphill, S. A., \& Smart, D. (2002). Temperament and social development. In P. K. Smith \& C. H. Hart (Eds.), Blackwell handbook of childhood social development (pp. 97-116). Oxford, England: Blackwell.

Sanson, A., \& Rothbart, M. K. (1995). Child temperament and parenting. In M. H. Bornstein (Ed.), Handbook of parenting, Volume 4: Applied and practical parenting (pp. 299-321). Mahwah, NJ: Lawrence Erlbaum Associates.

Scarr, S. (1992). Developmental theories for the 1990's: Development and individual differences. Child Development, 63, 1-19.

Scarr, S., \& McCartney, K. (1983). How people make their own environments. Child Development, 54 , 424-435.

Schneider, B. H., Atkinson, L., \& Tardif, C. (2001). Child-parent attachment and children's peer relationships: A quantitative review. Developmental Psychology, 37, 86-100.

Schwartz, D., Dodge, K. A., Pettit, G. S., \& Bates, J. E. (1997). The early socialization of aggressive victims of bullying. Child Development, 68, 665-675.

Shaffer, D. R. (2000). Social and personality development (4th ed.). Belmont, CA: Wadsworth Thomson Learning.

Shaw, D. S., Keenan, K., \& Vondra, J. I. (1994). Developmental precursors of externalizing behavior: Ages 1 to 3. Developmental Psychology, 30, 355-364.

Shield, A., \& Cicchetti, D. (1998). Reactive aggression among maltreated children: The contributions of attention and emotion dysreguation. Journal of Clinical Child Psychology, 27, 381-395. 
Shumow, L., Vandell, D. L., \& Posner, J. K. (1998). Harsh, firm, and permissive parenting in low-income families: Relations to children's academic achievement and behavioral adjustment. Journal of Family Issues, 19, 483-507.

Silverstein, L. B., \& Auerbach, C. F. (1999). Deconstructing the essential father. American Psychologist, 54, 397-407.

Siminoff, E. (2002). Genetic influences on conduct disorder. In J. Hill, \& B. Maughan (Eds.), Conduct disorders in childhood and adolescence. Cambridge, England: Cambridge University Press.

Siqueland, L., Kendall, P. C., \& Steinberg, L. (1996). Anxiety in children: Perceived family environments and observed family interaction. Journal of Clinical Child Psychology, 25, 225-237.

Skarpness, L. R., \& Carson, D. K. (1986). Temperament, communicative competence and the psychological adjustment of kindergarten children. Psychological Reports, 59, 1299-1306.

Smetana, J. G. (1994). Parenting styles and beliefs about parental authority. New Directions for Child Development, 66, 21-36.

Smith, C., Perou, R., \& Lesesne, C. (2002). Parent education. In M. H. Bornstein (Series Ed.), Handbook of Parenting, Vol. 4 (pp. 389-410). New Jersey: Lawrence Erlbaum Associates.

Spence, S. H., Donovan, C., \& Brechman-Toussaint, M. (2000). The treatment of childhood phobia: The effectiveness of a social skills training-based, cognitive-behavioural intervention, with and without parental involvement. Journal of Child Psychology and Psychiatry, 41, 713-726.

Sroufe, L. A., Egeland, B., \& Carlson, E. A. (1999). One social world: The integrated development of parent-child and peer relationships. In W. A. Collins \& B. Laursen (Eds.), Relationships as developmental contexts: The Minnesota symposia on child psychology (Vol. 30, pp. 241-261). Mahwah, NJ: Lawrence Erlbaum Associates.

Sroufe, L. A., \& Fleeson, J. (1986). Attachment and the construction of relationships. In W. W. Hartup \& Z. Rubin (Eds.), Relationships and development (pp. 51-72). Hillsdale, NJ: Lawrence Erlbaum Associates.

Stafford, L., \& Bayer, C. L. (1993). Interaction between parents and children. Newbury Park, CA: Sage.

Steinberg, L., Lamborn, S. D., Darling, N., Mounts, N. S., \& Dornbusch, S. M. (1994). Over-time changes in adjustment and competence among adolescents from authoritative, authoritarian, indulgent, and neglectful families. Child Development, 65, 754-770.

Steinkamp, M. W. (1989). Factors mediating the relationships between preschool children's play patterns and peer ratings: Verbal communication styles. Journal of Applied Developmental Psychology, 10, $505-525$.

Stocker, C., \& Dunn, J. (1990). Sibling relationships in childhood: Links with friendships and peer relationships. British Journal of Developmental Psychology, 8, 227-244.

Stoolmiller, M., Patterson, G. R., \& Snyder, J. (1997). Parental discipline and child antisocial behavior: A contingency-based theory and some methodological refinements. Psychological Inquiry, 8, 223-229.

Stormshak, E. A., Bierman, K. L., McMahon, R. J., \& Lengua, L. J. (2000). Parenting practices and child disruptive behavior problems in early elementary school. Journal of Clinical Child Psychology, 29, $17-29$.

Strassberg, Z., Dodge, K. A., Pettit, G. S., \& Bates, J. E. (1994). Spanking in the home and children's subsequent aggression toward kindergarten peers. Development and Psychopathology, 6, 445-461.

Straus, M. A., Sugarman, D. B., \& Giles-Sims, J. (1997). Spanking by parents and subsequent antisocial behavior of children. Archives of Pediatrics and Adolescent Medicine, 151, 761-767.

Taylor, A. B., \& Asher, S. R. (1984). Children's goals and social competence: Individual differences in a game-playing context. In T. Field, J. L. Roopnarine, \& M. Segal (Eds.), Friendships in normal and handicapped children (pp. 53-80). Norwood, NJ: Ablex.

Tellegen, A., Lykken, D. T., Bouchard, T. J., Jr., Wilcox, K. J., Segal, N. L., \& Rich, S. (1988). Personality similarity in twins reared apart and together. Journal of Personality and Social Psychology, 54, 10311039.

Thomas, A., \& Chess, S. (1977). Temperament and development. New York: Brunner-Mazel.

Travillion, K., \& Snyder, J. (1993). The role of maternal discipline and involvement in peer rejection and neglect. Journal of Applied Developmental Psychology, 14, 37-57.

Tremblay, R. E., Vitaro, E., Bertrand, L., LeBlanc, M., Beauchesne, H., Boileau, H., \& David, L. (1992). Parent and child training to prevent early onset of delinquency: The Montreal longitudinal study. 
In J. McCord \& R. E. Tremblay (Eds.), Preventing anti-social behavior: Interventions from birth through adolescence (pp. 117-138). New York: Guilford Press.

Van den Boom, D. (1994). The influence of temperament and mothering on attachment and exploration. Child Development, 65, 1457-1477.

Vandell, D. L. (2000). Parents, peer groups, and other socializing influences. Developmental Psychology, 36, 699-710.

Volling, B. L., \& Elins, J. L. (1998). Family relationships and children's emotional adjustment as correlates of maternal and paternal differential treatment: A replication with toddler and preschool siblings. Child Development, 69, 1640-1656.

Vuchinich, S., Bank, L., \& Patterson, G. R. (1992). Parenting, peers, and the stability of antisocial behavior in preadolescent boys. Developmental Psychology, 28, 510-521.

Wachs, T. D. (1999). The what, why, and how of temperament: A piece of the action. Child psychology: A handbook of contemporary issues (pp. 23-44). New York: Garland.

Wachs, T. D. (2000). Necessary but not sufficient: The respective roles of single and multiple influences on individual development. Washington, DC: American Psychological Association.

Wachs, T. D., Bishry, Z., Sobhy, A., McCabe, G., Galal, O., \& Shaheen, F. (1993). Relation of rearing environment to adaptive behavior of Egyptian toddlers. Child Development, 64, 586-604.

Wakschlag, L. S., \& Hans, S. L. (1999). Relation of maternal responsiveness during infancy to the development of behavior problems in high-risk youths. Developmental Psychology, 35, 569-579.

Webster-Stratton, C., \& Hammond, M. (1997). Treating children with early-onset conduct problems: A comparison of child and parent training interventions. Journal of Consulting and Clinical Psychology, 65, 93-109.

Weinstein, E. A. (1969). The development of interpersonal competence. In D. Goslin (Ed.), Handbook of socialization theory and research (pp. 753-775). Chicago: Rand McNally.

White, K. R., Taylor, M. J., \& Moss, V. D. (1992). Does research support claims about the benefits of involving parents in early intervention programs? Review of Educational Research, 62, 91-125.

Woodward, L., Taylor, E., \& Dowdney, L. (1998). The parenting and family functioning of children with hyperactivity. Journal of Child Psychology and Psychiatry, 39, 161-169.

Wu, P., Robinson, C. C., Yang, C., Hart, C. H., Olsen, S. F., Porter, C. L., Jin, S., Wo, J., \& Wu, X. (in press). Similarities and differences in mothers' parenting of preschoolers in China and the United States. International Journal of Behavioral Development.

Yang, C., Hart, C. H., Nelson, D. A., Porter, C. L., Olsen, S. F., Robinson, C. C., \& Jin, S. (in press). Associations among fathering, children's negative emotionality, and aggression in a Beijing Chinese sample. In R. Day \& M. Lamb (Eds.), Reconceptualizing and measuring fatherhood. Mahwah, NJ: Lawrence Erlbaum Associates.

Yoshikawa, H. (1994). Prevention as cumulative protection: Effects of early family support and education on chronic delinquency and its risks. Psychological Bulletin, 115, 28-54.

Zhou, Q., Eisenberg, N., Lousoya, S. H., Fabes, R. A., Reiser, M., Guthrie, I. K., Murphy, B. C., Cumberland, A. J., \& Shepard, S. A. (2002). The relations of parental warmth and positive expressiveness to children's empathy-related responding and social functioning: A longitudinal study. Child Development, 73, 893915.

Zigler, E., Taussig, C., \& Black, K. (1992). Early childhood intervention: A promising preventative for juvenile delinquency. American Psychologist, 47, 997-1006. 
